\title{
Phenotypic Evolution of The Wild Progenitor of Cultivated Barley (Hordeum Vulgare Subsp. Spontaneum (C. Koch) Thell.) Across Bioclimatic Regions In Jordan
}

Nawal Al Hajaj ( $\sim$ nawal_alhajaj@hotmail.com )

National Agricultural Research Center-NARC https://orcid.org/0000-0001-8836-7664

Stefania Grando

Alliance of Bioversity International and CIAT: Alliance of Bioversity International and International Center for Tropical Agriculture

Maysoon Ababnah

National Agricultural Research Centre

Nawar Alomari

National Agricultural Research Centre

Ahmad Albatianh

National Agricultural Research Centre

Jeehan Nesir

National Agricultural Research Centre

Hussain Migdadi

National Agricultural Research Centre

Yahya Shakhatreh

Arab Atomic Energy Agency (AAEA)

\section{Salvatore Ceccarelli}

Alliance of Bioversity International and CIAT: Alliance of Bioversity International and International Center for Tropical Agriculture

\section{Research Article}

Keywords: Environmental adaptation, Hordeum spontaneum, ecogeographical differentiation, phenotypic evolution, climate change, CWR

Posted Date: August 30th, 2021

DOl: https://doi.org/10.21203/rs.3.rs-802790/v1 
License: (c) (i) This work is licensed under a Creative Commons Attribution 4.0 International License. Read Full License 


\section{Abstract}

Climate change affects the evolutionary potential and the survival of wild plant populations by acting on fitness traits. Resurrection approach was applied to investigate the phenotypic changes during the evolution of the wild progenitor of cultivated barley, Hordeum spontaneum K. Koch in Jordan. We compared 40 Hordeum spontaneum K. Koch populations collected in Jordan in 1991 with 40 Hordeum spontaneum K. Koch populations collected from the same sites in 2014. In the comparison we included seven Hordeum vulgare checks (one local landrace and six improved varieties). The analysis of the phenotypic data showed that the populations were aggregated according to their ecological geographical pattern in two groups with a significant $(p<0.0001)$ correlation between groups. Four heritable traits, namely plant height, biological yield, number of tillers, and awn length, determined the phenotypic structure of the populations. The two populations collected at 23 years distance, diverged in two distinctive phenotypic structure categories; a conserved structure and an evolved structure with a reduction in the phenotypic trait diversity in the population collected in 2014. These results reveal the value of combining phenotypic and environmental data to understand the evolution and adaptation of the population to climate change over a long period and the consequences on the wild progenitor of cultivated barley collection to avoid loss of genetic materials.

\section{Key Message}

Wild relatives' evolution is considered as one of the main kinds of response and adaptation of natural stresses. This study demonstrates the response of wild barley Hordeum spontaneum to natural selection over a period of 23 years.

\section{Introduction}

Climate change threatens crop production and biodiversity (Lobell et al. 2011; Osborne et al. 2013), causing increasing concerns about the ability of food production to meet the needs of a fast-growing world population expected to reach 9-10 billion by 2050 (UN, 2015). Crop wild relatives (CWR) and progenitors may play an important role in raising agricultural productivity and sustainability (Lala et al. 2018). The value of CWR as actual or potential donors of genes has been estimated in $\$ 115$ billion per year worldwide in increased crop yields (Pimentel et al. 1997). Around seven hundred species out of estimated 50,000 to 60,000 crop and CWR species are considered of the highest global conservation priority (Maxted and Kell 2009). Despite their high potential value, climate change, loss of habitat (Jarvis et al. 2008; FAO 2013), and inadequate conservation, threaten many CWR species and their genetic diversity (Vincent et al. 2013). Phenotypic and genetic variation harbored by CWR along with their distribution range are the key to adapt and build resilience to ever changing environmental conditions (Frankham et al. 2010). Weather fluctuations play an important role in determining the vulnerability of the CWR's populations conserved in situ. Most of the studies of the changes of CWR genetic diversity over time used accessions conserved in gene banks (van de Wouw et al. 2010; Thormann et al. 2015). Few studies used the resurrection and re-collection approach (Franks et al. 2017) that allows the study of 
contemporary evolution and understand whether there have been evolutionary responses to environmental changes. The approach applied to changes in genetic diversity is useful to test the effectiveness of ex situ as compared to in situ conservation. (Che et al. 2011; Greene et al. 2014).

Barley (Hordeum vulgare L.) is one of the oldest domesticated crops (Zohary et al. 2012), presently one of the most important feed and food cereal ranking fourth for area harvested and production quantity after wheat, maize, and rice. It is the predominant cereal crop in marginal and drought prone areas in temperate environments, where other crops perform poorly or fail to survive. Therefore, in many nontropical dry areas it is the only possible rainfed crop that farmers can grow (Ceccarelli, 1994). Barley domestication took place in the Fertile Crescent (Harlan and Zohary 1966), and the Jordan Valley has been considered as one (although not the only) center of domestication (Badr et al. 2000; Mascher et al. 2016).

$H$. vulgare ssp. spontaneum (K. Koch) (hereafter referred to as $H$. spontaneum) is the wild progenitor of cultivated barley from which it differs for traits associated with the domestication process (Paterson et al. 1995). It is a valuable source of useful genes for crop improvement such as yield (von Korff et al. 2006), plant height under drought stress (Baum et al. 2003), drought and high temperature tolerance (Chen et al. 2008; Shakhatreh et al. 2010; Lakew et al. 2011, 2013), leaf-scald, and leaf rust resistance (Backes et al. 2003; Genger et al. 2003; von Korff et al. 2005; Repkova et al. 2006), seminal root characteristics (Grando and Ceccarelli 1995), and straw quality characteristics (Grando et al. 2005). The wild progenitor of barley is adapted to a broad range of eco-geographical conditions (Ivandic et al. 2002) despite its narrow geographical distribution that extends from $30^{\circ} \mathrm{N}$ to $40^{\circ} \mathrm{N}$ (Haas et al. 2019).

Evolutionary changes in wild plants communities distributed over a range of different environments such as the progenitor of cultivated barley, are caused by a combination of gene flow, genetic drifts, and selective evolutionary forces (Levin 1988; Barrett and Kohn 1991), such as divergent selection and local adaptation (Linhart and Grant 1996; Gram and Sork 2001). Environmental gradients can create contrasting selective pressures due to intra- and inter-specific competition (Fowler 1986; Linhart 1988) that shapes the genetic structure of plant populations because of environmental variables (Nevo 2001; Andrew et al. 2010; Jump and Peñuelas 2005; Michalski et al. 2010; Shi et al. 2011).

The correlation between genetic structure and eco-geographical diversity may not hold for all species and habitats (Maxted et al. 2008), such as wild oat in Jordan (Al-Hajaj et al. 2018). The genetic structure of $H$. spontaneum had been characterized across its distribution range (Russell et al. 2011; Jakob et al. 2014). An association between genetic diversity and environmental gradients and variables is reported in several studies (Baum et al. 1997; Pakniyat et al. 1997; Gupta et al. 2002; Liviero et al. 2002; Chen et al. 2004; Batchu et al. 2006). In Jordan, Shakhatreh et al. (2010) reported a correlation of genetic and phenotypic diversity with ecogeographical factors, while Thormann et al. (2016) reported that population genetic structure, spatial location, and climate were not correlated.

Jordan is in the transition zone, between arid and semiarid zones, with approximate distance of $350 \mathrm{~km}$ between the northern and the southern borders. It is characterized by arid climate, long dray season, and 
insufficient precipitation with an annual rainfall ranging from $50 \mathrm{~mm}$ in southern and eastern desert regions, to $600 \mathrm{~mm}$ in the north-western mountains. (Dahamsheh and Aksoy 2007), resulting in a substantial spatial variation of aridity over a short geographic distance, including changes in the flora composition (Zohary 1973; Freiwan and Kadioglu 2008). In addition to its climatic diversity, Jordan is home to $\mathrm{H}$. spontaneum and therefore well suited to study the diversity of the wild progenitor of cultivated barley in space and in time.

Many studies assessed the diversity of $H$. spontaneum in Jordan (Shakhatrah et al. 2010; Baloch et al. 2016; Shakhatreh et al. 2016; Thormann et al. 2016) and reported that Jordan is an important center of diversity of $H$. spontaneum (Baek et al. 2003).

The main objective of this paper is to expand the previous studies by comparing two large collections of H. spontaneum from Jordan made at 23 years distance from each other to investigate the effects of bioclimatic gradients on the phenotypic diversity. Additional objectives of this study are a) to obtain a better understanding of the structure of $H$. spontaneum collection in different climatic regions of Jordan and the effect of bioclimatic variables during the time interval, b) what is the strength of the structure pattern of germplasm in the two collection years, and assessing the potential of using ex-situ conservation; $c$ ) how does the measures of climate change associate with the changes in phenotypic traits.

\section{Methods}

\section{Plant materials}

The genetic material consisted of 91 barley entries including 84 populations of $H$. spontaneum, collected at two different times from 42 different collection sites in Jordan, one two-row landrace (Baladi), and six improved barley cultivars, three of which two-rows (Kv, Muta'a and Yarmouk) and three six-rows (Rum, ACSAD 176 and Athrouh). Of the eighty-four $H$. spontaneum populations forty-two were collected from 17 May to 5 June 1991 by the National Agricultural Research Center (NARC) in collaboration with the International Center for Agricultural Research in the Dry Areas (ICARDA) and forty-two were collected between 15 April and 15 June 2014 from the same sites where the collection was done in 1991. The original 1991 seed samples were stored for long term in sealed aluminum foil bags, in a standard household deep freeze at $-18^{\circ} \mathrm{C}$. The detailed data about the collection sites visited in 1991 included geographical coordinates (latitude and longitude) and made it possible to repeat the collection in 2014 from the same sites. The populations were clustered into five groups (Table 1) according to bioclimatic zones in Jordan (WorldClim at http://www.worldclim.org/bioclim). The year of collection are hereafter referred to as collection time T1 $=1991$ and collection time T2 = 2014 . 
Table 1

List of 40 Hordeum vulgare subsp. spontaneum populations according to bioclimatic zones in Jordan

\begin{tabular}{|c|c|c|c|c|c|c|}
\hline Population & Name Zone & Province & Location & Altitude & Longitude & latitude \\
\hline 1 & Arid med,cool & Mafraq & West Mafraq & 745 & 3611 & 3219 \\
\hline 2 & Arid med,cool & Mafraq & Bal'ama & 660 & 3603 & 3213 \\
\hline 3 & Arid med,cool & Amman & $\begin{array}{l}\text { Al Castal } \\
\text { village }\end{array}$ & 770 & 3556 & 3143 \\
\hline 4 & Arid med,cool & Karak & $\begin{array}{l}\text { Al Gdieda } \\
\text { village }\end{array}$ & 935 & 3550 & 3117 \\
\hline 5 & Arid med,cool & Karak & Aie & 960 & 3538 & 3107 \\
\hline 6 & Arid med,cool & Tafila & Abour & 1335 & 3542 & 3046 \\
\hline 7 & Arid med,Warm & Mafraq & Al Zatari & 700 & 3617 & 3217 \\
\hline 8 & Arid med,Warm & Tafila & Aimah village & 860 & 3532 & 3051 \\
\hline 9 & Semi arid med, cool & Tafila & Al Rashadieh & 1450 & 3534 & 3042 \\
\hline 10 & Semi arid med, cool & Tafila & Ain El Bieda & 1140 & 3537 & 3046 \\
\hline 11 & Semi arid med, cool & Tafila & Al La'aban & 685 & 3540 & 3053 \\
\hline 12 & Semi arid med, cool & Ma'an & $\begin{array}{l}\text { Shoubak } \\
\text { Agri. }\end{array}$ & 1450 & 3532 & 3031 \\
\hline 13 & Semi arid med, cool & Ma'an & Al Minshieh & 1335 & 3532 & 3030 \\
\hline 14 & $\begin{array}{l}\text { Semi arid med, } \\
\text { warm }\end{array}$ & Irbid & $\begin{array}{l}\text { Al- } \\
\text { Ashrafeyeh }\end{array}$ & 485 & 3540 & 3227 \\
\hline 15 & $\begin{array}{l}\text { Semi arid med, } \\
\text { warm }\end{array}$ & Irbid & Kafr-Awan & 460 & 3538 & 3224 \\
\hline 16 & $\begin{array}{l}\text { Semi arid med, } \\
\text { warm }\end{array}$ & Irbid & KafrRakib & 510 & 3539 & 3226 \\
\hline 17 & $\begin{array}{l}\text { Semi arid med, } \\
\text { warm }\end{array}$ & Irbid & DairAbi-S'eid & 200 & 3539 & 3228 \\
\hline 18 & $\begin{array}{l}\text { Semi arid med, } \\
\text { warm }\end{array}$ & Ajlun & Ousra & 630 & 3538 & 3225 \\
\hline 19 & $\begin{array}{l}\text { Semi arid med, } \\
\text { warm }\end{array}$ & $\begin{array}{l}\text { Jordan } \\
\text { valley }\end{array}$ & DeirAbi Said & 300 & 3539 & 3229 \\
\hline 20 & $\begin{array}{l}\text { Semi arid med, } \\
\text { warm }\end{array}$ & Jarash & $\begin{array}{l}\text { Kafkafa } \\
\text { village }\end{array}$ & 880 & 3556 & 3219 \\
\hline 21 & $\begin{array}{l}\text { Semi arid med, } \\
\text { warm }\end{array}$ & Jarash & Al Abbara & 370 & 3554 & 3215 \\
\hline
\end{tabular}




\begin{tabular}{|c|c|c|c|c|c|c|}
\hline Population & Name Zone & Province & Location & Altitude & Longitude & latitude \\
\hline 22 & $\begin{array}{l}\text { Semi arid med, } \\
\text { warm }\end{array}$ & Jerash & $\begin{array}{l}\text { Al-Faisal } \\
\text { nursery }\end{array}$ & 320 & 3553 & 3215 \\
\hline 23 & $\begin{array}{l}\text { Semi arid med, } \\
\text { warm }\end{array}$ & Zarqa & Al Alouk & 610 & 3555 & 3210 \\
\hline 24 & $\begin{array}{l}\text { Semi arid med, } \\
\text { warm }\end{array}$ & Balqa' & Zaai & 1000 & 3540 & 3202 \\
\hline 25 & $\begin{array}{l}\text { Semi arid med, } \\
\text { warm }\end{array}$ & Balqa' & Zai & 1000 & 3540 & 3202 \\
\hline 26 & $\begin{array}{l}\text { Semi arid med, } \\
\text { warm }\end{array}$ & Amman & Naour & 880 & 3548 & 3151 \\
\hline 27 & $\begin{array}{l}\text { Semi arid med, } \\
\text { warm }\end{array}$ & Amman & Al-Rouda & 920 & 3548 & 3150 \\
\hline 28 & $\begin{array}{l}\text { Semi arid med, } \\
\text { warm }\end{array}$ & Madaba & Jreneh & 845 & 3548 & 3141 \\
\hline 29 & $\begin{array}{l}\text { Semi arid med, } \\
\text { warm }\end{array}$ & Karak & $\begin{array}{l}\text { Al Karak } \\
\text { district }\end{array}$ & 935 & 3545 & 3117 \\
\hline 30 & $\begin{array}{l}\text { Semi arid med, } \\
\text { warm }\end{array}$ & Karak & Al Wasiea & 1060 & 3545 & 3110 \\
\hline 31 & $\begin{array}{l}\text { Semi arid med, } \\
\text { warm }\end{array}$ & Karak & Muta & 1220 & 3542 & 3104 \\
\hline 32 & Semi aridmed,warm & Tafila & $\begin{array}{l}\text { Garandal } \\
\text { village }\end{array}$ & 1370 & 3533 & 3042 \\
\hline 33 & $\begin{array}{l}\text { Semi arid med, } \\
\text { warm }\end{array}$ & Ma'an & $\begin{array}{l}\text { Al Jarba } \\
\text { village }\end{array}$ & 1330 & 3531 & 3019 \\
\hline 34 & $\begin{array}{l}\text { Semi arid med, } \\
\text { warm }\end{array}$ & Ma'an & Wadi Musa & 1500 & 3528 & 3023 \\
\hline 35 & $\begin{array}{l}\text { Sub humid } \\
\text { mediterranean }\end{array}$ & Irbid & Kufr-Youba & 570 & 3547 & 3230 \\
\hline 36 & $\begin{array}{l}\text { Sub humid } \\
\text { mediterranean }\end{array}$ & Irbid & Sammo' & 400 & 3541 & 3229 \\
\hline 37 & $\begin{array}{l}\text { Sub humid } \\
\text { mediterranean }\end{array}$ & Irbid & Sakeb-Jarash & 1000 & 3547 & 3216 \\
\hline 38 & $\begin{array}{l}\text { Sub humid } \\
\text { mediterranean }\end{array}$ & Balqa' & Al-Yazedeyeh & 955 & 3544 & 3201 \\
\hline 39 & $\begin{array}{l}\text { Sub humid } \\
\text { mediterranean }\end{array}$ & Balqa' & Al Yazidieh & 955 & 3544 & 3201 \\
\hline 40 & $\begin{array}{l}\text { Sub humid } \\
\text { mediterranean }\end{array}$ & Balqa' & Al Rumman & 490 & 3549 & 3205 \\
\hline
\end{tabular}




\section{Phenotypic evaluation}

The phenotypic evaluation was conducted at Maru experimental research station of the National Agricultural Research Center (NARC) in the Irbid governorate of Jordan $\left(32^{\circ} 3620.16 \mathrm{~N}\right.$ and $32^{\circ} 54$ 3.95E) during the growing seasons 2014-2015 and 2015-2016. Maru is considered a high input condition location under rainfed conditions with a long-term average rainfall of $414 \mathrm{~mm}$. Ten seeds of each population were sown in plots of three rows $0.5 \mathrm{~m}$ long, with $17 \mathrm{~cm}$ between the rows and $0.5 \mathrm{~m}$ between plots. The experimental design was a partially replicated ( $\mathrm{p}$-rep) row and column design (Cullis et al. 2006). Of the eighty-four populations, 69 were un-replicated and 15 were replicated twice based on the number of seeds available; the seven $\mathrm{H}$. vulgare entries were repeated three times resulting in 120 plots arranged in ten columns and 12 rows. Randomization was done with DiGGer (http://www.austatgen.org/software), a software that generates efficient experimental designs for nonfactorial experiments with plots arranged in rows and columns (Coombes 2009; Cullis et al. 2006). Two H. spontaneum populations (no. 41 and 42) from T1 and one population (no. 41) from T2 failed to emerge and were considered as missing together with entry no. 42 from T2 because the corresponding entry from T1 was not available (Fig. 1 and Table 1). The experiments were conducted under rainfed conditions and weeds were controlled by hand weeding. Plants were bagged at the booting stage before flowering to avoid cross-fertilization with the materials in adjacent plots, contamination, and seed loss.

Phenotypic data were collected on the following characters:

1. Plant emergence (EM in \%): the percent of emerged seed;

2. Days to heading (DH in days): number of days from emergence to the day when the awns appeared above the ligule of the flag leaf in $50 \%$ of plants in the plot;

3. Days to maturity (DM in days): number of days from emergence to the day when the peduncle was entirely discolored in $90 \%$ of the plants in the plot;

4. Gain filling duration (GF in days): number of days from heading date to the first spikelet shuttering in the spike;

5. Plant height (PH in $\mathrm{cm})$ : at maturity, measured from the ground level to the base of the spike and expressed as average of all plants in the plot;

6. Tiller number (TN as number): total number of tillers per plant expressed as average of all plants in a plot;

7. Awn length ( $A w L$ in $\mathrm{cm}$ ): length from the top of the spike to the longest awn expressed as average of all plants in the plot;

8. Biological yield (BY in $\mathrm{g} / \mathrm{m} 2$ ): total above-ground dry matter yield; 
All phenotypic data were recorded on all entries except for plant height, tiller number and biological yield, that were not collected on $\mathrm{Kv}$, because the sample was lost.

\section{Climatic conditions}

Climate data were obtained from the WorldClim database version 1.4 (http://www.worldclim.org), a global and freely available source of climate data layers generated by interpolating average monthly climate data from weather stations (Hijmans et al. 2005). Layers for current climate conditions (19502000) for the 19 bioclimatic variables were downloaded (Table 2). The values for the 19 variables were extracted for each collection site using DIVA-GIS. Collection sites covered a range in altitude from 200 to $1500 \mathrm{~m}$ a.s.l., a range in latitude from $30^{\circ} 19^{\prime}$ to $32^{\circ} 30 \mathrm{~N}$, and in longitude from $35^{\circ} 56^{\prime} \mathrm{E}$ to $36^{\circ} 03 \mathrm{E}$. The collection sites covered five bioclimate regions with annual precipitation ranging from 152 to $491 \mathrm{~mm}$, and a mean annual temperature ranging from $12.9^{\circ}$ to $20.4 \mathrm{C}$.

Table 2 Coding of bioclimatic variables according to WorldClim at http://www.worldclim.org/bioclim. 


\begin{tabular}{|ll|}
\hline Code & Code Description \\
\hline Bioclim1 & Annual Mean Temperature \\
\hline Bioclim2 & Mean Diurnal Range (Mean of monthly (max temp-min temp)) \\
\hline Bioclim3 & Isothermality (Bioclim2/ Bioclim7) (* 100) \\
\hline Bioclim4 & Temperature Seasonality (standard deviation *100) \\
\hline Bioclim5 & Max Temperature of Warmest Month \\
\hline Bioclim6 & Min Temperature of Coldest Month \\
\hline Bioclim7 & Temperature Annual Range (Bioclim5- Bioclim6) \\
\hline Bioclim8 & Mean Temperature of Wettest Quarter \\
\hline Bioclim9 & Mean Temperature of Driest Quarter \\
\hline Bioclim10 & Mean Temperature of Warmest Quarter \\
\hline Bioclim11 & Mean Temperature of Coldest Quarter \\
\hline Bioclim12 & Annual Precipitation \\
\hline Bioclim13 & Precipitation of Wettest Month \\
\hline Bioclim14 & Precipitation of Driest Month \\
\hline Bioclim15 & Precipitation Seasonality (Coefficient of Variation) \\
\hline Bioclim16 & Precipitation of Wettest Quarter \\
\hline Bioclim17 & Precipitation of Driest Quarter \\
\hline Bioclim18 & Precipitation of Warmest Quarter \\
\hline Bioclim19 & Precipitation of Coldest Quarter \\
\hline B
\end{tabular}

\section{Data analysis}

\section{Environmental Characterization}

The diversity of the phytogeographic regions in Jordan attracted the interest to study the genetic materials of the area, which can be divided into four major regions: the Mediterranean (subhumid and semiarid Mediterranean), the Irano-Turanian (arid Mediterranean), the Saharo-Arabian, and the Sudanian regions (Zohary 1973; Al-Eisawi 1985, 1996; Freiwan and Kadioglu 2008). Al-Eisawi $(1985,1996)$ added five extra subdivisions according to decreasing precipitations and increasing temperature: (i) sub-humid Mediterranean; (ii) semiarid Mediterranean; (iii) arid Mediterranean; and (iv) Saharan Mediterranean (referred to as sub-humid, semiarid, arid and Saharan bioclimate, respectively). 
Principal component analysis (PCA) was used to study the correlation patterns of all bioclimatic variables and characterize the differences in the entries studied.

\section{Phenotypic data analysis}

The data were analyzed by a combined analysis of variance (ANOVA) over two years. Genotype $x$ Year (GY) interaction was computed by using a weighted analysis of variance (ANOVA) where the weight of each mean was computed as the inverse of the square root of the estimated variance of that mean. The weighted sum of squares was compared against the value of a chi-square distribution with GY interaction degree of freedom to provide information on GY interaction's significance. Statistical analysis was carried out using GenStat Edition 19 (VSN 2019). To evaluate the phenotypic diversity of the populations, mean, standard deviation (SD), coefficient of variation (CV), and range were computed. Heritability was estimated from the variance components from the ANOVA mean squares. Broad-sense heritability ( $\mathrm{h}^{2}$ ) was calculated by dividing the genetic variance $\left(\sigma_{g}\right)$ by the phenotypic variance $\left(\sigma_{p}\right)$ (Allard 1999).

The correlation between the phenotypic traits and the geographical variables were performed separately for the two collection times, T1 and T2 and tested using the Spearman rank test. Mantel test was carried out to examine the relationship between phenotypic differences between populations collected at T1 and T2 and the geographical and environmental variables.

The phenotypic distance for the recorded traits was used to assess the differences between the populations collected at T1 and T2. Principal component analysis (PCA) was carried out to identify the variables accounting for the multivariate dataset variance, on the recorded morphological traits after standardization. The PCA results were summarized in a scatterplot for each collection time, and the cultivate barley (six and two-row types) with each collection time.

A biplot (Gabriel 1971) projection of the original axes (variables) was also included in the scatterplot. In the biplot, angles between vectors are proportional to the correlations between the variables, angles $<90^{\circ}$ indicate positive correlation, angles $\approx 90^{\circ}$ indicate independence, and angles $>90^{\circ}$ indicate negative correlation. PCA, scatter plot and biplots were performed using Past software version 4 (Hammer et al. 2001).

\section{Results}

\section{Environmental characterization.}

The principal component analysis in Fig. 2 revealed two major groups based on the relationships between environmental variables, and the variables within each group were highly and positively correlated. The first two PCA explained $79.93 \%$ of the total variation (Fig. 2). The first group was divided into two sub-groups as one was grouped according to the precipitations variables, while the other was grouped according to the diurnal temperature variables. Altitude did not group at all. The populations collected in the south of the country were discriminated from the populations collected in the north on 
PC1 that was dominated by high temperature and low rainfall. The effect of the dominant weather conditions on the populations was stronger than bioclimate type. Most of the environmental variables have large effects on the ordination of the environments as shown by the lengths of their vectors. By contrast, mean diurnal range, mean temperature of wettest quarter, the temperatures seasonality, precipitation seasonality, and altitude had a lower effect as shown by their shorter vectors (Fig. 2).

\section{Phenotypic data analysis}

\section{Analysis of variance}

The combined analysis of variance (ANOVA) revealed a significant difference among genotypes for most of the traits recorded (Table 3). Genotype effects accounted for $66.4 \%, 77.7 \%$, and $65.9 \%$ of the total variance for plant height, awns length, and biological yield, respectively. By contrast, year effects accounted for $63 \%, 89 \%$, and $73 \%$ of the total variance for days to heading, days to maturity and grain filling duration, respectively. The same trend was observed for $Y, G$ and $G \times Y$ interaction for number of tillers and percent seed emergence. The performances of the populations were stable across the two years and their response patterns were similar in the case of plant height, awns length, and biological yield. The number of tillers and percent seed emergence were less affected by the year variability. The other traits showed relatively distinct patterns of responses corresponding to the years variability. Broadsense heritability ranged from 0.49 for tiller number to 0.82 for awn length: these are relatively large values resulting from both high additive genetic variance and low residual variance (Table 3 ).

Table 3 Combined analysis of variance for percent of seed emergence (Em), days to flowering (Dh), days to maturity (Dm), grain filling duration (Gf in days), tiller number (Tn), plant height $\mathrm{Ph}$ ), awn length (Awl), biological yield (By) and corresponding heritability $\left(\mathrm{H}^{2}\right)$. 


\begin{tabular}{|c|c|c|c|c|c|c|c|}
\hline Traits & & $\mathrm{df}$ & SS & MS & SS\% & P-value & $\mathrm{H}^{2}$ \\
\hline \multirow[t]{4}{*}{$\mathrm{Em}$} & Years & 1 & 8.4 & 8.4 & 3.2 & 0.02 & \\
\hline & Geno & 87 & 125.7 & 1.5 & 47.4 & 0.004 & 0.50 \\
\hline & Years. x Geno & 87 & 131.2 & 1.5 & 49.5 & 0.002 & \\
\hline & Total & 157 & 265.4 & & & & \\
\hline \multirow[t]{4}{*}{$\mathrm{Dh}$} & Years & 1 & 373.4 & 373.4 & 62.8 & $<.001$ & \\
\hline & Geno & 87 & 118.5 & 1.4 & 19.9 & 0.014 & 0.54 \\
\hline & Years x Geno & 87 & 102.8 & 1.2 & 17.3 & 0.11 & \\
\hline & Total & 175 & 594.7 & & & & \\
\hline \multirow[t]{4}{*}{$\mathrm{Dm}$} & Years & 1 & 1719.7 & 1719.1 & 89.10 & $<.001$ & \\
\hline & Geno & 87 & 119.3 & 1.4 & 6.18 & 0.012 & 0.56 \\
\hline & Years x Geno & 87 & 91.0 & 1.1 & 4.71 & 0.365 & \\
\hline & Total & 175 & 1929.9 & & & & \\
\hline \multirow[t]{4}{*}{ Gf } & Years & 1 & 575.7 & 575.7 & 73.2 & $<.001$ & \\
\hline & Geno & 87 & 124.9 & 1.5 & 15.9 & 0.005 & 0.61 \\
\hline & Years x Geno & 87 & 85.6 & 0.98 & 10.9 & 0.522 & \\
\hline & Total & 175 & 786.2 & & & & \\
\hline \multirow[t]{4}{*}{ Tn } & Years & 1 & 274.5 & 274.2 & 27.4 & $<.001$ & \\
\hline & Geno & 86 & 356.3 & 4.1 & 35.6 & 0 & 0.49 \\
\hline & Years X Geno & 86 & 370.9 & 4.3 & 37.0 & 0 & \\
\hline & Total & 173 & 1001.4 & & & & \\
\hline \multirow[t]{4}{*}{$\mathrm{Ph}$} & Years & 1 & 105.1 & 105.1 & 18.2 & $<.001$ & \\
\hline & Geno & 86 & 383.2 & 4.5 & 66.4 & $<.001$ & 0.80 \\
\hline & Years x Geno & 86 & 88.8 & 1.1 & 15.4 & 0.395 & \\
\hline & Total & 175 & 577.1 & & & & \\
\hline \multirow[t]{4}{*}{ By } & Years & 1 & 58.9 & 58.9 & 12.2 & $<.001$ & \\
\hline & Geno & 86 & 302.5 & 3.6 & 65.9 & $<.001$ & 0.75 \\
\hline & Years X Geno & 86 & 97.1 & 1.2 & 21.2 & 0.195 & \\
\hline & Total & 173 & 458.5 & & & & \\
\hline
\end{tabular}




\begin{tabular}{|llllllll|} 
Awl & Years & 1 & 30.6 & 30.6 & 5.4 & $<.001$ & \\
Geno & 87 & 437.9 & 5.5 & 77.7 & $<.001$ & 0.82 \\
Years X Geno & 87 & 94.7 & 1.2 & 16.8 & 0.125 & \\
Total & 175 & 563.4 & & & & \\
\hline
\end{tabular}

The correlation coefficients between the phenotypic traits are shown in Table 4. Number of tillers was positively and significantly correlated with biological yield, plant height, and awns length. Also, awns length, plant height, and biological yield were positively and significantly correlated. Number of days to heading was negatively correlated with grain filling duration $(r=-0.28)$ and number of tillers $(r=-0.27)$. By contrast, number of days to maturity was positively and highly correlated with grain filling duration ( $r$ $=0.46)$ and negatively correlated with plant height and biological yield (Table 4).

Table 4 The correlation coefficients among phenotypic traits of wild barley population.

\begin{tabular}{|c|c|c|c|c|c|c|c|c|}
\hline Traits & $\mathrm{Em}$ & $\mathrm{Dh}$ & $\mathrm{Dm}$ & Gf & $\mathrm{Tr}$ & $\mathrm{Ph}$ & By & Awl \\
\hline $\mathrm{Em}$ & 1 & & & & & & & \\
\hline $\mathrm{Dh}$ & -0.06 & 1 & & & & & & \\
\hline $\mathrm{Dm}$ & -0.17 & $0.67 * \star$ & 1 & & & & & \\
\hline Gf & -0.10 & $-0.28 *$ & $0.46^{\star \star}$ & 1 & & & & \\
\hline $\mathrm{Tr}$ & 0.05 & $-0.27 *$ & $-0.25^{\star}$ & -0.04 & 1 & & & \\
\hline $\mathrm{Ph}$ & 0.01 & -0.11 & -0.13 & -0.04 & $0.50 \star \star$ & 1 & & \\
\hline By & 0.09 & -0.19 & $-0.24^{\star}$ & -0.04 & $0.74^{\star \star}$ & $0.67 * *$ & 1 & \\
\hline Awl & 0.13 & -0.09 & -0.17 & -0.09 & $0.50 \star \star$ & $0.45^{\star *}$ & $0.65^{\star \star *}$ & 1 \\
\hline
\end{tabular}

In this study, we used principal component analysis to describe the populations distribution by considering both morphological and agronomic data. Considering an eigenvalue greater than one, the PCA results showed that the first three principal components of T1 and two principal components of T2 accounted for $75 \%$ and $64 \%$ of the overall variation, respectively (Table 5). The variation in PC1, which explained $41 \%$ and $38 \%$ of the total variation on collection times T1 and T2, was correlated mainly with the number of tillers per plant, plant height, biological yield, and awns length. The grain filling duration showed the most significant loading to $\mathrm{PC2}$, while the number of days to heading and maturity were the traits contributing to PC3, which explained the variation $20 \%$ and $14 \%$ in PC2 and PC3 of the total variation of collection time T1, respectively. However, these three traits showed the highest contribution to PC2 by explaining $26.2 \%$ of the total variations on collection time T2. 
Table 5 Eigenvectors and eigenvalues of the first PCs of collection time study traits of wild barley populations.

\begin{tabular}{llllll} 
& \multicolumn{2}{l}{ Collection time T1 } & \multicolumn{2}{l}{ Collection time T2 } \\
\hline Traits & \multicolumn{2}{l}{ Eigenvectors } & \multicolumn{2}{l}{ Eigenvectors } \\
\hline Em & PC1 & PC2 & PC3 & PC1 & PC2 \\
\hline Dh & 0.09 & 0.02 & 0.24 & 0.01 & -0.37 \\
\hline Dm & -0.41 & -0.79 & 0.43 & -0.24 & 0.46 \\
\hline Gf & -0.68 & 0.02 & 0.72 & -0.08 & 0.71 \\
\hline Tr & -0.29 & 0.89 & 0.33 & 0.15 & 0.31 \\
\hline Ph & 0.66 & -0.12 & 0.29 & 0.53 & 0.17 \\
\hline By & 0.79 & 0.11 & 0.26 & 0.46 & -0.01 \\
\hline Awl & 0.89 & 0.06 & 0.28 & 0.52 & -0.03 \\
\hline Eigenvalues & 0.80 & -0.13 & 0.19 & 0.38 & 0.14 \\
\hline$\%$ of total variance explained & 41.03 & 20.15 & 14.73 & 38.06 & 26.2 \\
\hline$\%$ cumulative variance explained & 41.03 & 61.18 & 75.91 & 38.06 & 64.26
\end{tabular}

The biplot highlighted some notable differences between the eighty populations resulting from two collecting times (Fig. 3). Half of the collected populations, regardless of collection time, were characterized by early heading and maturity, high number of tillers, tall plants, long awns, and high biological yield, were mainly from the northern part of the country. The biplot differentiated the populations in four groups as follows; Group 1 (G1) included 24 populations (collected from the same twelve sites both at T1 and T2) characterized by early heading and maturity, high number of tillers, tall plants, long awns, and high biological yield; Group 2 (G2) included 22 populations (collected from the same eleven sites both at T1 and T2) characterized by late heading and maturity, few tillers, short plant height and awns and low biological yield; the 34 populations representing the remaining 17 collection sites, showed a different performance depending on the collection time. Theses 34 populations were classified in two groups; Group 3 (G3) included 16 populations (representing eight collection sites), of which 8 populations collected at T1 showed the same performance as the populations in Group 1, while the same populations collected at T2 showed a performance similar to the populations classified in Group 2; 2) Group 4 (G4) included 18 populations (representing nine collection sites) of which 9 populations collected at T1 had a performance similar to the populations classified in Group 2, while the same populations collected at T2 had a performance similar to the populations classified in Group 1. 
Phenotypic distances assess the differentiation between the population groups, where the smallest phenotypic distances ( $d$ = between 2.94 and 3.88) were found within populations for each group, while the largest phenotypic distances ( $d$ = between 5.02 and 5.50) were found between populations groups with different performance (Table 6). Cluster analyses of phenotypic distances aggregated the populations into two major groups (Fig. 4). The first cluster included the T1G2, T2G2, T1G4, and T2G3, where all population were characterized by late heading and maturity, few tillers, short plant height and awns and low biological yield. The second cluster included T1G1, T2G1, T1G3, and T2G4, where all population were characterized by early heading and maturity, a high number of tillers, tall plants, long awns, and high biological yield.

Table 6 Phenotypic distance determined between 8 morphological traits in the Jordanian populations of Hordeum vulgare spp. spontaneum from two collection times.

\begin{tabular}{|lllllllll|}
\hline Population & T1G1 & T1G2 & T1G3 & T1G4 & T2G1 & T2G2 & T2G3 & T2G4 \\
\hline T1G1 & 3.70 & & & & & & & \\
T1G2 & 5.09 & 3.55 & & & & & & \\
T1G3 & 4.14 & 5.16 & $\mathbf{2 . 9 4}$ & & & & & \\
T1G4 & 5.11 & 4.47 & 5.50 & 3.49 & & & & \\
T2G1 & 4.48 & 5.14 & 4.52 & 5.06 & 3.88 & & & \\
T2G2 & 4.99 & 4.24 & 5.12 & 4.05 & 5.06 & 3.12 & & \\
\hline T2G3 & 5.10 & 4.30 & 5.43 & 4.28 & 5.22 & 4.22 & 3.32 & \\
\hline T2G4 & 4.09 & 4.95 & 3.80 & 5.02 & 4.16 & 4.89 & 4.77 & 3.05 \\
\hline
\end{tabular}

Trait diversity amongst the grouping of population is presented in Table 7. In general, the diversity among each collection times showed that T1 has relatively wider diversity (mean CV across the 8 traits 18.45\%) and its groups represent the maximum variations (12.25\% to 19.05), while T2 (mean CV across the 8 traits $17.44 \%$ ) and its groups represent the variations from $11.93-16.23 \%$. The highest variability amongst traits was found within G1T1 (19.05\%) followed by G2 T2 (16.23\%), followed by G4 T2 (14.9\%).

Table 7 Mean, minimum, maximum, SD and CV for emergence plant\%, days to flowering and maturity, day of grain filling, tiller number, plant height, biological yield and awn length for wild barley according to collection time. 
Collection time

Em Dh Dm Gf $\operatorname{Tr}$ Ph By Awl

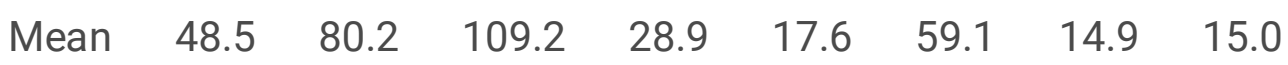

Collection T1

$\begin{array}{llll}\mathrm{Sd} & 12.2 & 3.1 & 3.2\end{array}$

$\begin{array}{lllll}2.1 & 4.6 & 11.2 & 6.7 & 2.7\end{array}$

$\begin{array}{llll}\text { Cv } & 25.2 & 3.9 & 3.0\end{array}$

$\begin{array}{lllll}7.3 & 26.2 & 18.9 & 44.8 & 18.3\end{array}$

Collection T2

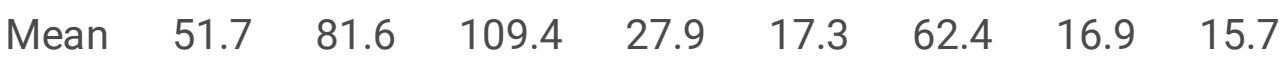

$\begin{array}{lllllllll}\mathrm{Sd} & 13.4 & 3.2 & 3.1 & 2.9 & 3.5 & 11.8 & 6.5 & 3.0\end{array}$

$\begin{array}{lllllllll}\text { Cv } & 25.9 & 3.9 & 2.8 & 10.4 & 20.1 & 18.9 & 38.3 & 19.2\end{array}$

$\begin{array}{llllllllll}\text { Group1, T1 (T1G1) } & \text { Mean } & 47.5 & 79.1 & 108.9 & 29.6 & 18.9 & 62.3 & 15.6 & 15.7\end{array}$

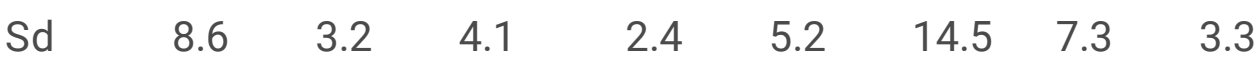

$\begin{array}{lllllllll}\text { Cv } & 18.1 & 4.0 & 3.7 & 8.0 & 27.6 & 23.2 & 47.0 & 20.8\end{array}$

$\begin{array}{llllllllll}\text { Group1, T2 (T2G1) } & \text { Mean } & 53.8 & 81.8 & 109.0 & 27.3 & 19.5 & 69.6 & 20.8 & 17.3\end{array}$

$\begin{array}{lllllllll}\mathrm{Sd} & 10.9 & 3.6 & 2.6 & 3.1 & 3.1 & 8.0 & 4.0 & 1.8\end{array}$

$\begin{array}{lllllllll}\text { Cv } & 20.4 & 4.4 & 2.4 & 11.2 & 16.0 & 11.5 & 19.0 & 10.5\end{array}$

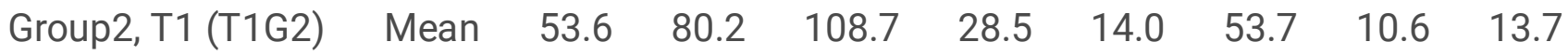

$\begin{array}{lllllllll}\mathrm{Sd} & 12.7 & 2.5 & 3.0 & 1.6 & 2.0 & 4.8 & 2.4 & 2.3\end{array}$

$\begin{array}{lllllllll}\text { Cv } & 23.6 & 3.1 & 2.8 & 5.7 & 14.4 & 9.0 & 22.6 & 16.8\end{array}$

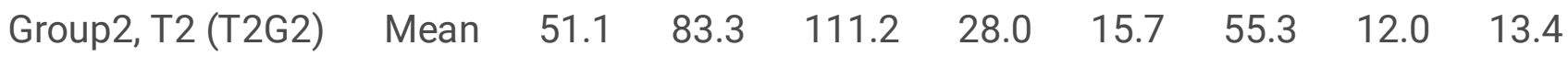

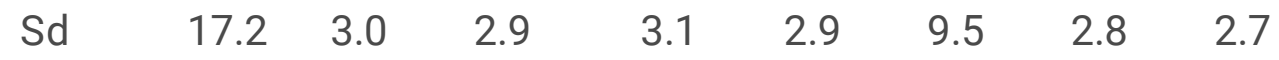

$\begin{array}{lllllllll}\text { Cv } & 33.5 & 3.7 & 2.6 & 11.2 & 18.6 & 17.1 & 23.2 & 19.9\end{array}$

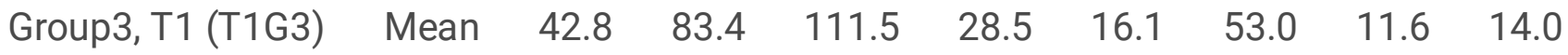

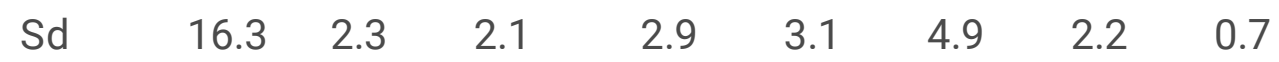

$\begin{array}{lllllllll}\mathrm{Cv} & 38.2 & 2.8 & 1.8 & 10.1 & 19.4 & 9.2 & 18.6 & 4.7\end{array}$

$\begin{array}{llllllllll}\text { Group3, T2(T2G3) } \quad \text { Mean } & 48.1 & 80.0 & 106.1 & 26.3 & 18.7 & 72.1 & 22.5 & 17.8\end{array}$

$\begin{array}{lllllllll}\mathrm{Sd} & 8.7 & 2.1 & 1.3 & 1.3 & 2.8 & 8.4 & 8.2 & 3.0\end{array}$

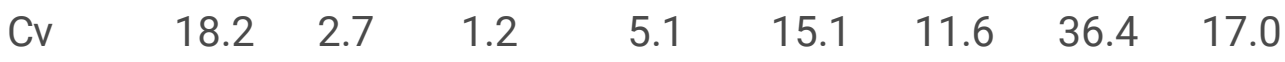

$\begin{array}{llllllllll}\text { Group4, T1(T1G4) } & \text { Mean } & 48.6 & 79.0 & 108.0 & 28.9 & 21.7 & 66.8 & 22.2 & 16.6\end{array}$

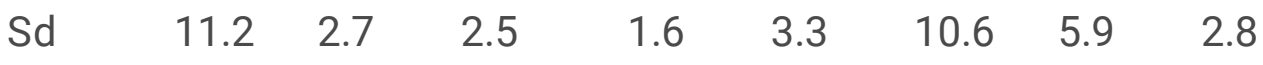

$\begin{array}{lllllllll}\text { Cv } & 23.0 & 3.5 & 2.3 & 5.6 & 15.0 & 15.9 & 26.7 & 17.1\end{array}$




\begin{tabular}{rlllllllll} 
Group4, T2 (T2G4) & Mean & 52.8 & 80.8 & 110.8 & 30.1 & 14.9 & 52.7 & 12.8 & 14.4 \\
\hline & Sd & 15.8 & 2.9 & 2.9 & 2.4 & 3.0 & 8.5 & 2.9 & 2.3 \\
\hline & Cv & 30.0 & 3.6 & 2.6 & 7.9 & 20.2 & 16.1 & 22.9 & 16.1
\end{tabular}

There were different levels of variations in both collection times for the traits we recorded (Table 7). A). The two collection times T1 and T2 showed a coefficient of variation ranging from $10.4-44.8 \%$ for all traits, except for days to heading and days to maturity for which the coefficient of variation varied from 2.8-3.9\%. The populations collected at T1 in G1 were diversified in the stable traits more than populations from collection T2 except in emergence percentage and grain filling. The populations from collection T2 in both $\mathrm{G} 2$ and $\mathrm{G} 3$ diversified in all traits more than the population from collection T1 except in the emergence percentage and grain filling where the populations from collection T1 showed more variation in G3. Also, the populations' collected at T2 in group 4 diversified in plant height and the number of tillers more than those collected at T1, though the populations collected at T1 diversified in percent emergence, biological yield, and awn lengths more than those collected at $\mathrm{T} 2$.

\section{Phenotypic variation and the impact of environmental conditions}

Mantel test showed significant relationship between bioclimate variables and altitudes within the four sub population groups (G1, G2, G3 and G4) collected at T1 and T2 $(r=0.76, p<0.0001 ; r=0.81, p<$ $0.0001 ; r=0.70, p<0.0001 ; r=0.76, p<0.0001$, respectively), and among populations $(r=0.79, p<$ 0.001). On the other hand, no relationship was found between all groups with geographical variables, except for populations in group $\mathrm{G} 2$ and among populations were bioclimatic variables correlated moderately with altitudes $(r=0.33, p=0.01 ; r=0.30, p=0.01$, respectively).

The correlations between agronomic traits, bioclimatic variables, and altitude for both collection time T1 and T2 are shown in Figure 5. The populations biological yield and awns length relatively correlated significantly and positively with the bioclimate variables in collection times T1 and T2. The correlations between agronomic traits and bioclimate variables showed a more varied pattern among populations in G3 and G4 than G1 and G2 in both collection times. Indeed, the grain filling period of populations in G1 collected at $\mathrm{T} 1$ correlated positively with precipitation variables and significantly with precipitation seasonality, and days to heading correlated positively with temperature variables at T2. In the case of populations of $\mathrm{G} 2$ collected at $\mathrm{T} 1$, their days to heading, days to maturity were significantly correlated with temperature variables, while in the same populations collected at $\mathrm{T} 2$, tiller number was positively correlated with precipitations variables. In the populations of G3 collected at T1, only grain filling periods was positively correlated with precipitation variables, and negatively with the bioclimate variables. By contrast, days to heading and days to maturity were significantly and positively correlated with temperature variables. In the populations of G4 collected at T2, percent emergence and biological yield were positively correlated with precipitations variables. 
A principal component analysis of the phenotypic data including control varieties is shown in Figure 6. In the case of the population collected at T1, the first two axes accounted for $34.29 \%$ and $24.25 \%$ of the total variation, respectively. In the case of the populations collected at T2, the first two axes accounted for $33.18 \%$ and $28.69 \%$ of the total variation, respectively. The PCA separated the control varieties in two groups (Figure 6). The biological yield and tiller number of the $H$. spontaneum populations, namely collected at T2 were higher than the improved cultivars as compared with the $H$. spontaneum populations collected at T1. They were also taller and with a longer grain filling period

\section{Discussion}

Our study used the resurrection and re-collection approach (Nevo et al. 2012; Thormann et al. 2017) to investigate the phenotypic changes of $40 \mathrm{H}$. spontaneum populations that were collected from 40locations at two collection times $\mathrm{T} 1=1991$ and $\mathrm{T} 2=2014$.

The study identified adaptive changes of $H$. spontaneum populations from different eco-geographic regions in Jordan partly associated with the impact of environmental variables on the evolution of phenotypic diversity. Because of the substantial variation in the environmental conditions of the collection sites, we assume that the collection is a representative sample of the overall distribution of diversity and population structure of $H$. spontaneum across Jordan. The increasing variation in environmental conditions is expected to increase the additive genetic variance for fitness (Shaw and Shaw 2014), and the high heritability estimates found in the 40 populations suggests a strong evolutionary potential. We found a clear differentiation between the phenotypic traits measured in the populations collected at 23 years interval. This suggests that the populations evolved over the years, showing that the $\mathrm{H}$. spontaneum in Jordan diverged in response to ecogeographical diversity. The response to different selection pressure due to local/regional variations is apparent in the phenotypic changes, such as flowering time (Qian et al. 2020). Principal component analysis grouped the 40 populations in four groups based on phenological and agronomic traits. These traits are characterized by high heritability and stability across years. Each group responded differently to ecogeographical variables before collection time T1 and between the two collection times, which is consistent with the work of Bedada et al. (2014) and of Morrell et al. (2003), as two out of the four groups maintained their phenotypic structure (Fig. 3). In contrast, a similar study (Thormann et al. 2017) reported no changes in the genetic structure of the populations despite the evidence of changes in the climatic conditions. Therefore, this study adds to the growing body of literature by reporting that crop wild relative diversity like $H$. spontaneum is evolving and adapting in response to environmental variables (Shakhatreh at al. 2016; Nevo et al. 2012; Thormann et al. 2016, 2017; Qian et al. 2020).

\section{Environmental variation among sites}

There is substantial evidence supporting the hypothesis that the climate has been changing since the early twentieth century (IPCC 2001; Jones et al. 2001). Climate change already has and will even have more adverse impact on agricultural productivity in the Arab region due to increase in temperature and 
precipitation uncertainty (RICCAR 2017) as well as sea level rise leading to increase in soil salinity in some countries. The 4th assessment report of the Intergovernmental Panel on Climate Change (IPCC) predicts that climate change is location specific (Ceccarelli and Grando, 2020). Based on climatic changes during 1973-2003, the following climate scenarios were projected for Jordan for the time horizon 2010-2040: an increase of average annual temperature from $1^{\circ} \mathrm{C}$ to $1.5^{\circ}$ and a $10 \%-25 \%$ reduction in monthly precipitations specifically, in March and April in agreement with the outcomes presented by Intergovernmental Panel on Climate Change predictions (Saba et al. 2014). The forty $H$. spontaneum populations used in this study, were collected from five bioclimatic regions in Jordan. Bioclim layers, provided by World Clim climatic data, are used in a range of studies (Phillips et al. 2006; Parra-Quijano et al. 2012 a and b; Kantar et al. 2015; Thormann et al. 2016).

Based on the climate variables and altitude, the forty populations were classified into two major groups according to the longitudinal distribution of distinct habitats type; the populations from the central and northern areas grouped in one group while those from the southern areas grouped in a second one confirms what found in a study on the genetic structure of $H$. spontaneum in Jordan (Thormann et al. 2016). In other words, the 40 populations used in this study grouped eco-geographically in agreement with the bioclimatic regions in which they were collected, because the populations collected from climatically similar sites grouped together regardless of the geographic distances between the collection sites. Adaptation of the $H$. spontaneum was selectively driven by the frequency of droughts and by the temperature gradients (Hübner et al. 2009).

\section{Phenotypic variation}

Our result revealed that $H$. spontaneum populations differ in their degree of phenotypic diversity either within time or across the 23 years interval. We examined the phenotypic variation that could be useful in developing improved cultivars or could be a model of plant species evolution (Volis et al. 2000; Shakhatreh et al. 2010; Nevo et al. 2012; Thormann et al. 2017). A CV of at least $10 \%$ is a good indication of broad diversity in varieties and landraces of wheat (Dotlacil et al. 2000). Therefore, and on this basis, we concluded that the phenotypic diversity in the population collected in 1991 was comparatively higher than the diversity in the population collected in 2014. This is in disagreement with the findings of a similar study (Thormann et al. 2017). The phenotypic diversity explains the evolutionary potential under both genetic drift and natural selection in the temporal pattern of the genetic variation (Mitchell-Olds et al. 2007; Ellegren and Sheldon 2008). H. spontaneum populations are diverse in their biomass, plant height, and awn length, while the tiller number is characterized by high stability across the two years (Table 3 ). The heritability of these traits in both years was high, ranging, on average, from $44-73 \%$, and associated positively and significantly with those traits (Table 5). On the contrary, the number of days to heading and maturity, and grain filling period were not stable across years, and were negatively correlated with both plant height and biomass. Based on this, we conclude that the differences between collection time reflects heritable adaptation. $H$. spontaneum can maintain a long stem even under severe drought conditions (Ceccarelli 2014), and particularly the H. spontaneum from the Mediterranean basin countries, is characterized by having awns (Börner et al. 2005). Awn length and plant height are related to larger 
straw yield and increased duration of photosynthetic activity (Kjack and Witters 1974; Ceccarelli et al. 1987). Geographical and climate variables positively affect the morphological variations among $H$. spontaneum populations has been demonstrated in several studies (Baek et al. 2003; Batchu et al. 2006; Hübner et al. 2009 and 2013; Jakob et al. 2014; Russell et al. 2016).

It is assumed that the phenotypic variation is more affected by the selection, being the direct target. Biomass, plant height, awn length and tiller number had mainly re-ordinate the population collection between the two collection times (T1 and T2) (Fig. 3). The results shown that the collection conducted at two different times revealed two response patterns. In fact, two of the four population groups mostly maintained their response over time, while the other two population groups evolved as a response to environmental pressure over the 23 years. Two groups of the populations showed unexpected responses to environment variables for a long period of natural selection, similarly to the findings of Thormann et al. (2017), who reported that the overall Jordanian H. spontaneum population structures were conserved. Maintenance of phenotypic and adaptive diversity is likely another population strategy to maintain fitness in variable environments (Kind and Masel 2007; Olofsson et al. 2009). By contrary, the other two groups of the population showed a response to the environmental variation that led to an increase in its the additive genetic fitness variance (Shaw and Shaw 2014).

\section{Environmental role in population phenotypic differentiation}

Our field experiment showed that the populations used were different by four phenotypic patterns across different environments in response to climate change with a different level in their phenotypic diversification as found by Jump and Penuelas (2005). Root et al. (2003), and Wang et al. (2014). The phenotypic structure for the four groups (G1, G2, G3, and G4) correlated highly and significantly with the environment variables $(r=0.76 ; r=0.81, r=0.70, r=0.76, p<0.0001$, respectively), but not with geographical variables. The associations between environmental variables and phenotypic traits could result from neutral evolutionary processes, but such associations may also show a selective and adaptive process. Environmental pressure in stressful habitats might select the most significant phenotypic diversity levels, probably because of their buffering effects in heterogeneous environments (Nevo 2001). Therefore, two of the groups of $H$. spontaneum populations showed a difference in flowering time because of the ecogeographical adaption (Bedada et al. 2014; Morrell et al. 2003; Nevo et al. 1986; Nevo et al. 2012), regardless of the heterogeneity of the environment (Nevo et al. 2012).

H. spontaneum is a highly self-pollinated species (Goodwillie et al. 2005), with an average outcrossing rate of $1-2 \%$ (Abdel-Ghani et al. 2004). However, outcrossing rates up to $10 \%$ have been reported (Nevo 1992). Although self-pollinated species are expected to have a lower intra-population genetic diversity, the $H$. spontaneum populations from the Fertile Crescent usually show a high intra-population genetic diversity (Baek et al. 2003; Hübner et al. 2009). Many of the studies reported the presence of phenotypic diversity both between and within $\mathrm{H}$. spontaneum populations in Jordan and in other countries (Elberse et al. 2003; Hübner et al. 2013; Nice et al. 2017; Shakhatreh et al. 2010; Thormann et al. 2017; Van Rijn et al. 2000; Volis et al. 2002). 
We can explain the phenotypic differentiation among collection times of $H$. spontaneum populations based on the evidence mentioned above; half of the populations (40 out of 80 ), namely those that we classified in group 1 and group 2, did not show evidence of evolutionary changes over the 23 years between the two collections. The populations of $\mathrm{G} 1$ collected at $\mathrm{T} 1$ had a higher level of phenotypic diversity that the populations of the same group collected at T2. The distance between the individual points of collection strongly suggests that gene flow -between populations by seed or pollen dispersal is rare and not related to geographical variables. Fu et al. (2019), reported similar results with a wild emmer wheat study. Our results are in line with a study of wild rice (Gao et al. 2000). On the contrary, the populations of $\mathrm{G} 2$ collected at T2 showed a higher phenotypic diversity in all traits than the populations of the same group collected at T1. Thormann (2017), reported similar results and this could be attributed to an increased dispersal of seeds and pollen with a consequent gene flow from cultivated barley to $H$. spontaneum (Hübner et al. 2013).

Seventeen populations, namely those classified in G3 and G4 showed evidence of evolution during the 23 years between the two collection times. Population phenology shifted relative to the timing of climate events critically important to its fitness (Bertin 2008), and flowering time changed in both groups. We assume that the small-scale variations between local environment at the collection sites might contribute to the divergence of flowering time between populations. In wild plants a shift to early flowering has been reported as a response to the global climate change (Craufurd and Wheeler 2009; Brunet and LarsonRabin 2012; Bock et al. 2014). The populations in G3 and collected at T2 shifted in the direction of a lower phenotypic diversity for most traits and late flowering compared with those in the same group but collected 23 years earlier (T1). The population in G4 collected at T2 shifted to a higher phenotypic diversity for most traits and early flowering T2 compared with those in the same group and collected at T1. G3 and G4 correlated positively and significantly with precipitation variables and with temperature variables, respectively, supporting the hypothesis that population response to rapid climate change is driven by adaptive evolution in adjusting phenotypic variation for traits such as the allocation of biomass or biological yield and phenology (Jump and Penuelas 2005; Root et al. 2003; Wang and Ottle et al. 2014).

Mediterranean climate is characterized by strong inter-annual and seasonal weather fluctuations (Etterson 2004; Peleg et al. 2008). Jordan is in the transition zones between Sub Humid-Mediterranean and arid bioclimates over short geographic distances. Within approximately $350 \mathrm{~km}$ from north to south, rainfall varies from as high as $600 \mathrm{~mm}$ in north western mountains to as low as $50 \mathrm{~mm}$ in the southern and eastern desert regions (Dahamsheh and Aksoy 2007). Variability in soil moisture causes different selection pressures in different bioclimatic regions on traits such as flowering time and time of seed germination (Hamasha and Hensen 2009 and Hamasha et al. 2013). Notably, percent of seed emergence showed less diversity in populations in both $\mathrm{G} 1$ and $\mathrm{G} 2$ collected at $\mathrm{T} 1$ than in those collected at $\mathrm{T} 2$, while the diversity of percent of seed emergence was higher in populations collected at T1 in both G3 and $\mathrm{G} 4$ than in those collected at T2. The percent of seed emergence in the two groups showing evidence of evolution (G3 and G4), correlated positively with annual precipitations, Thus, the differences in phenotypic diversity between populations from different bioclimatic regions may have been caused by 
local adaptation rather than solely by demographic processes (Hamasha et al. 2013), as adaptive process to the climate gradients (Michalski et al. 2010). This result is in agreement with many studies (for example Johansson et al. 2013).

The study emphasized the importance for plant breeding programs of the material collected at either T1 or T2, because it might possess important adaptive traits to improve cultivated barley for adaptation $\mathrm{t}$ climate change. The populations collected in 2014 performed generally better than the populations collected in 1991 for most of the traits examined when compared to the improved varieties used as checks. Because $H$. spontaneum evolve, newly collected populations may contain a higher frequency of adaptive traits than population in the gene bank, thus should be an actively conserved throughout the geographical range (Shakhatreh et al. 2010).

We assume that the phenotypic changes observed in this study with $H$. spontaneum populations collected in a time span of 23 years, represent an adaptive response to avoid/escape the increasing level of abiotic stresses associated with environmental changes. In this study, based on the analysis of the evolutionary fate of the morphological traits variation in the populations collected over a long period of environmental changes, we concluded that the phenotypic variation among the present populations increased significantly improving the level of local adaptation. Moreover, through the temporal analysis of changes in the expression of morphological traits, we found that the heritable traits affected by natural selection were fixed in all the present populations and would together orchestrate different patterns of flowering times to adapt to the environment changes. This study represents a novel example to understand the phenotypic basis of parallel evolution in natural populations. It provides informative phenotypic information for crop improvement in the face of the rapidly growing world populations and continuous global climate change. Finally, we suggest further genetic investigations to examine the level of changes and natural selection power that might hide by phenotypic trait.

\section{Declarations}

Acknowledgments We thank the International Treaty on Plant Genetic Resources for Food and Agriculture, which supported the collections of Hordeum spontaneum (Grant No. Pr-176- Jordan). We also thank theNational Agricultural Research Centre (NARC) team for their help in this research: Mr. Ziad Tahabsom from the biodiversity and medicinal plant department, Ms. Muna Saba from the Environment and Climate Change Directorate, the Maru team for technical help in the field experiments, and Dr. Imke Thormann for help in obtaining bioclimate variables data.

\section{Conflict of interest}

The authors declare that they have no conflict of interest.

\section{References}


1. Abdel-Ghani AH, Parzies HK, Omary A, Geiger HH (2004) Estimating the outcrossing rate of barley landraces and wild barley populations collected from ecologically different regions of Jordan. Theor Appl Genet 109:588-595

2. Al-Eisawi DM (1985) Vegetation in Jordan. In: Hadidi A (ed) Studies in the history and archaeology of Jordan. Dept of Antiquities, Hashemite Kingdom of Jordan, and Amman. Routledge and Kegan Paul, London, pp 45-57

3. Al-Eisawi DM (1996) Vegetation of Jordan. UNESCO Cairo Office, Egypt

4. Allard RW (1999) Principles of plant breeding, 2nd edn. John Wiley \& Sons, New York

5. Al-Hajaj N, Peterson GW, Horbach C, Al-Shamaa K, Tinker NA, Fu YB (2018) Genotyping-bysequencing empowered genetic diversity analysis of Jordanian oat wild relative Avena sterilis. Genet Resour Crop Evol 65(8):2069-2082

6. Andrew RL, Wallis IR, Harwood CE, Foley WJ (2010) Genetic and environmental contributions to variation and population divergence in a broad spectrum foliar defense of Eucalyptus tricarpa. Ann Bot 105(5):707-717

7. Backes G, Madsen LH, Jaiser H, Stougaard J, Herz M, MohlerV, Jahoor A (2003) Localization of genes for resistance against Blumeria graminis $\mathrm{f}$. sp. hordei and Puccinia graminis in a cross between a barley cultivar and wild barley (Hordeum vulgare subsp. spontaneum) line. Theor Appl Genet 106:353-362. PMID: 1258-2863

8. Badr A, Müller K, Schäfer-Pregl R, El Rabey H, Effgen S, Ibrahim HH, Pozzi C, Rohde W, Salamini F (2000) On the origin and domestication history of barley (Hordeum vulgare). Molecular Biology Evolution 17(4):499-510. https://doi.org/10.1093/oxfordjournals.molbev.a026330

9. Baek HJ, BeharavA, Nevo E (2003) Ecological-genomic diversity of microsatellites in wild barley Hordeum spontaneum populations in Jordan. Theor Appl Genet 106:397-410

10. Baloch AW, Baloch MJ, Ali M, Baloch M, Jogi Q, Baloch AM, Weining S (2016) Genetic diversity and structure analysis in wild and landraces of barley from Jordan by using ISJ markers. Pak J Bot 48(2):637-644

11. Barrett SC, Kohn JR (1991) Genetic and evolutionary consequences of small population size in plants: implications for conservation. In: Falk DA, Holsinger KE (eds) Genetics and Conservation of Rare Plants. Oxford University Press, Oxford, pp 3-30

12. Batchu AK, Zimmermann D, Schulze-Lefert P, Koprek T (2006) Correlation between hordatine accumulation, environmental factors and genetic diversity in wild barley (Hordeum spontaneum $\mathrm{C}$. Koch) accessions from the Near East Fertile Crescent. Genetica 127:87-99. https://doi.org/10.1007/s10709-005-2484-2

13. Baum BR, Nevo E, Johnson DA, Beiles A (1997) Genetic diversity in wild barley (Hordeum spontaneum $\mathrm{C}$. Koch) in the Near East: a molecular analysis using Random Amplified Polymorphic DNA (RAPD) markers. Genet Resour Crop Evol 44(2):147-157

14. Baum M, Grando S, Backes G, Jahoor A, Sabbagh A, Ceccarelli S (2003) QTLs for agronomic traits in the Mediterranean environment identified in recombinant inbred lines of the cross 'Arta' $\mathrm{x} H$. 
spontaneum 41 - 1. Theor Appl Genet 107:1215-1225

15. Bedada G, Westerbergh A, Nevo E, Korol A, Schmid KJ (2014) DNA sequence variation of wild barley Hordeum spontaneum (L.) across environmental gradients in Israel. Heredity 112:646-655

16. Bertin RI (2008) Plant phenology and distribution in relation to recent climate change. The $\mathrm{J}$ of the Torrey Botanical Society 135(1):126-146. https://doi.org/10.3159/07-RP-035R.1

17. Bock A, Sparks TH, Estrella N, Jee N, Casebow A, Menzel A (2014) Changes in first flowering dates and flowering duration of 232 plant species on the island of Guernsey. Glob Change Biol 20(11):3508-3519. https://doi.org/10.1111/gcb.12579

18. Börner A, Schöafer M, Schmidt A, Grau M, Vorwald J (2005) Associations between geographical origin and morphological characters in bread wheat (Triticum aestivum L.). Plant Genetic Resources $3(3): 360-372$

19. Brunet J, Larson-Rabin Z (2012) The response of flowering time to global warming in a high-altitude plant: the impact of genetics and the environment. Botany 90(4):319-326. https://doi.org/10.1139/b2012-001

20. Ceccarelli S (1994) Specific adaptation and breeding for marginal conditions. Euphytica 77:205-219

21. Ceccarelli S, Grando S, Van Leur JAG (1987) Genetic diversity in barley landraces from Syria and Jordan. Euphytica 36:389-405

22. Ceccarelli S (2014) Drought. In: Jackson M, Ford-Lloyd BV, and Parry ML, (eds). Plant Genetic Resources and Climate Change. CABI International, pp 221-235

23. Ceccarelli S, Grando S (2020) Evolutionary plant breeding as a response to the complexity of climate change. IScience 23(12):101815

24. Che YH, Yang YP, Yang XM, Li XQ, Li LH (2011) Genetic diversity between ex situ and in situ samples of Agropyron cristatum (L.) Gaertn. based on simple sequence repeat molecular markers. Crop Pasture Science 62(8):639-644. https://doi.org/10.1071/CP11065

25. Chen G, Li C, Shi Y, Nevo E (2008) Wild barley, Hordeum spontaneum, a genetic resource for crop improvement in cold and arid regions. Sciences in cold arid regions1:0115-0124

26. Chen G, Suprunova T, Krugman T, Fahima T, Nevo E (2004) Ecogeographic and genetic determinants of kernel weight and colour of wild barley (Hordeum spontaneum) populations in Israel. Seed Sci Res 14(2):137-146. https://doi.org/10.1079/SSR2004163

27. Coombes NE (2009) DiGGeR design search tool in R. http://nswdpibiom.org/austatgen/software

28. Craufurd PQ, Wheeler TR (2009) Climate change and the flowering time of annual crops. J Exp Bot 60(9):2529-2539. https://doi.org/10.1093/jxb/erp196

29. Cullis BR, Smith AB, Coombes NE (2006) On the Design of Early Generation Variety Trials with Correlated Data. Journal of Agricultural Biological Environmental Statistics 11:381-393

30. Dahamsheh A, Aksoy H (2007) Structural characteristics of annual precipitation data in Jordan. Theoret Appl Climatol 88:201-212 
31. Dotlacil L, Hermuth J, Stehno Z, Manev M (2000) Diversity in European winter wheat landraces and obsolete cultivars. Czech Journal of Genetics Plant Breeding 36:29-36

32. Elberse AM, Van Damme JMM, Van Tienderen PH (2003) Plasticity of growth characteristics in wild barley (Hordeum spontaneum) in response to nutrient limitation. J Ecol 91(3):371-382. https://doi.org/10.1046/j.1365-2745.2003.00776.x

33. Ellegren $\mathrm{H}$, Sheldon BC (2008) Genetic basis of fitness differences in natural populations. Nature 452(7184):169-175

34. Endresen DTF (2010) Predictive association between trait data and ecogeographic data for Nordic barley landraces. Crop Sci 50(6):2418-2430

35. Etterson JR (2004) Evolutionary potential of Chamaecrista fasciculata in relation to climate change. I. Clinal patterns of selection along an environmental gradient. in the Great Plains Evolution 58(7):1446-1458. https://doi.org/10.1111/j.0014-3820.2004.tb01726.x

36. FAO (2013) Report of the fourteenth regular session of the commission on genetic resources for food and agriculture. CGRFA 14/13/report. http://www.fao.org/nr/cgrfa/cgrfameetings/cgrfacomm/fourteenth-reg/en/

37. Fowler $\mathrm{N}$ (1986) The role of competition in plant communities in arid and semiarid regions. Annual review of ecology Systematics 17:89-110

38. Frankham R, Ballou JD, Briscoe DA (2010) Introduction to conservation genetics, 2nd edn. Cambridge University Press, Cambridge

39. Franks SJ, Hamann E, Weis AE (2017) Using the resurrection approach to understand contemporary evolution in changing environments. Evol Appl 11:17-28

40. Freiwan M, Kadioglu M (2008) Spatial and temporal analysis of climatological data in Jordan. Int J Climatol 28(4):521-535. https://doi.org/10.1002/joc.1562

41. Fu YB, Peterson GW, Horbach C, Konkin DJ, Beiles A, Nevo E (2019) Elevated mutation and selection in wild emmer wheat in response to 28 years of global warming. Proceedings of the National Academy of Sciences 116 (40): 20002-20008

42. Gabriel KR (1971) The biplot graphic display of matrices with application to principal component analysis. Biometrika 58:453-467

43. Gao L, Chen W, Jiang W, Ge S, Hong D, Wang X (2000) Genetic erosion in northern marginal population of the common wild rice Oryza rufipogon Griff. and its conservation. revealed by the change of population genetic structure Hereditas 133(1):47-53. https://doi.org/10.1111/j.16015223.2000.00047.x

44. Genger RK, Williams KJ, Raman H, Read BJ, Wallwork H, Burdon JJ, Brown AHD (2003) Leaf scald resistance genes in Hordeum vulgare and Hordeum vulgare ssp. spontaneum: parallels between cultivated and wild barley. Aust J Agric Res 54(12):1335-1342

45. Goodwillie C, Kalisz S, Eckert C (2005) The evolutionary enigma of mixed mating systems.in plants: occurrence, theoretical explanations, and empirical evidence. Annu Rev Ecol Evol Syst 36:47-79. https://doi.org/10.1146/annurev.ecolsys.36.091704.175539 
46. Gram WK, Sork VL (2001) Association between environmental and genetic heterogeneity in forest tree populations. Ecology 82(7):2012-2021. https://doi.org/10.1890/0012-9658(2001)082[2012: ABEAGH]2.0.CO;2

47. Grando S, Ceccarelli S (1995) Seminal root morphology and coleoptile length in wild (Hordeum vulgare ssp. spontaneum) and cultivated (Hordeum vulgare ssp. vulgare) barley. Euphytica 86:73-80

48. Grando S, Baum M, Ceccarelli S, Goodchild A, Jaby El-Haramein F, Jahoor A, Backes G (2005) QTLs for straw quality characteristics identified in recombinant inbred lines of a Hordeum vulgare $\mathrm{H}$. spontaneum cross in a Mediterranean environment. Theor Appl Genet 110:688-695

49. Greene SL, Kisha TJ, Yu L-X, Parra-Quijano M (2014) Conserving plants in gene banks and nature: investigating complementarity with Trifolium thompsonii Morton. PLOS one 9(8):e105145. https://doi.org/10.1371/journal.pone.0105145

50. Gupta PK, Sharma PK, Balyan HS, Roy JK, Sharma S, Beharav A, Nevo E (2002) Polymorphism at rDNA loci in barley and its relation with climatic variables. Theor Appl Genet 104:473-481. PMID: 12582721

51. Haas M, Schreiber M, Mascher M (2019) Domestication and crop evolution of wheat and barley: Genes, genomics, and future directions. Journal of integrative plant biology 61(3):204-225

52. Hamasha HR, Hensen I (2009) Seed germination of four Jordanian Stipa spp: differences in temperature regimes and seed provenances. Plant Species Biol 24(2):127-132. https://doi.org/10.1111/j.1442-1984.2009.00247.x

53. Hamasha HR, Schmidt-Lebuhn AN, Durka W, Schleuning M, Hensen I (2013) Bioclimatic regions influence genetic structure of four Jordanian Stipa species. Plant Biol 15(5):882-891. https://doi.org/10.1111/j.1438-8677.2012.00689.x

54. Hammer $\varnothing$, Harper DA, Ryan PD (2001) PAST: Paleontological statistics software package for education and data analysis. Palaeontologia electronica 4(1):9

55. Harlan JR, Zohary D (1966) Distribution of wild wheats and barley. Science 153(3740):1074-1080

56. Hijmans RJ, Cameron SE, Parra JL, Jones PG, Jarvis A (2005) Very high-resolution interpolated climate surfaces for global land areas. A Journal of the Royal Meteorological Society 25(15):19651978

57. Hübner S, Hüffken M, Oren E, Haseneyer G, Stein N, Graner A, Schmid K, Fridman E (2009) Strong correlation of wild barley (Hordeum spontaneum) population structure with temperature and precipitation variation. Mol Ecol 18(7):1523-1536. https://doi.org/10.1111/j.1365294X.2009.04106.X

58. Hübner S, Bdolach E, Ein-Gedy S, Schmid KJ, Korol A, Fridman E (2013) Phenotypic landscapes: phenological patterns in wild and cultivated barley. Journal Evolutionary Biology 26(1):163-174. https://doi.org/10.1111/jeb.12043

59. IPCC (Intergovernmental Panel on Climate Change), (2001), Climate Change 2001, Impacts, Adaptation, and Vulnerability. Contribution of Working Group II to the IPCC Third Assessment Report (TAR). Cambridge University Press, Cambridge, UK 
60. Ivandic V, Hackett CA, Nevo E, Keith R, Thomas WTB, Forster BP (2002) Analysis of sequence repeats (SSRs) in wild barley from the Fertile Crescent: associations with ecology, geography and flowering time. Plant Mol Biol 48:511-527

61. Jakob SS, Roedder D, Engler JO, Shaaf S, Oezkan H, Blattner FR, Kilian B (2014) Evolutionary history of wild barley (Hordeum vulgare subsp. spontaneum) analyzed using multilocus sequence data and paleodistribution modeling. Genome Biology Evolution 6(3):685-702. https://doi.org/10.1093/gbe/evu047

62. Jarvis A, Lane A, Hijmans RJ (2008) The effect of climate change on crop wild relatives. Agr Ecosyst Environ 126(1-2):13-23. https://doi.org/10.1016/j.agee.2008.01.013

63. Johansson J, Bolmgren K, Jonzén N (2013) Climate change and the optimal flowering time of annual plants in seasonal environments. Glob Change Biol 19(1):197-207. https://doi.org/10.1111/gcb.12006

64. Jump AS, Penuelas J (2005) Running to stand still: adaptation and the response of plants to rapid climate change. Ecol Lett 8(9):1010-1020. https://doi.org/10.1111/j.1461-0248.2005.00796.x

65. Kantar MB, Sosa CC, Khoury CK, Castañeda-Álvarez NP, Achicanoy HA, Rieseberg LH (2015) Ecogeography and utility to plant breeding of the crop wild relatives of sunflower (Helianthus annuus L.). Front Plant Sci 6:841. https://doi.org/10.3389/fpls.2015.00841

66. Kind OD, Masel J (2007) The evolution of bet-hedging adaptations to rare scenarios. Theor Popul Biol 72(4):560-575. https://doi.org/10.1016/j.tpb.2007.08.006

67. Kjack JL, Witters RE (1974) Physiological activity of awns in Isolines of Atlas Barley1.Crop Science 14(2): 243-248. https://doi.org/10.2135/cropsci1974.0011183X001400020003xb

68. Lakew B, Eglinton J, Henry RJ, Baum M, Grando S, Ceccarelli S (2011) The potential contribution of wild barley (Hordeum vulgare spp. spontaneum) germplasm to drought resistance of cultivated barley (Hordeum vulgare spp. vulgare). Field Crops Research 120: 161-168

69. Lakew B, Henry RJ, Eglinton J, Baum M, Ceccarelli S, Grando S (2013) SSR analysis of introgression of drought tolerance from the genome of Hordeum spontaneum into cultivated barley (Hordeum vulgare ssp. vulgare). Euphytica191(2): 231-243. https://doi.org/10.1007/s10681-012-0795-9

70. Lala S, Amri A, Maxted N (2018) Towards the conservation of crop wild relative diversity in North Africa: Checklist, prioritization and inventory. Genet Resour Crop Evol 65(1):113-124

71. Levin DA (1988) Local differentiation and the breeding structure of plant populations. In: Gottlieb LD, Jain SK (eds) Plant evolutionary biology. Chapman and Hall, New York, pp 305-329

72. Linhart YV (1988) Intrapopulation differentiation in annual plants. III. The contrasting effects of intraand interspecific competition. Evolution 42:1047-1064

73. Linhart YB, Grant MC (1996) Evolutionary significance of local genetic differentiation in plants. Annu Rev Ecol Syst 27:237-277. https://doi.org/10.1146/annurev.ecolsys.27.1.237

74. Liviero L, Maestri E, Gulli M, Nevo E, Marmiroli N (2002) Ecogeographic adaptation and genetic variation in wild barley, application of molecular markers targeted to environmentally regulated genes. Genet Resour Crop Evol 49:133-144. https://doi.org/10.1023/A:1014792509087 
75. Lobell DB, Schlenker W, Costa-Roberts J (2011) Climate trends and global crop production since 1980. Science 333(6042):616-620

76. Mascher M, Schuenemann VJ, Davidovich U, Marom N, Himmelbach A, Hübner S, Korol A, David M, Reiter E, Riehl S, Schreiber M (2016) Genomic analysis of 6,000-year-old cultivated grain illuminates the domestication history of barley. Nat Genet 48:1089-1093. https://doi.org/10.1038/ng.3611

77. Maxted N, Dulloo ME, Ford-Lloyd BV, Iriondo MJ, Jarvis A (2008) Gap analysis: a tool for complementary genetic conservation assessment. Diversity Distribution 14(6):1018-1030. https://doi.org/10.1111/j.1472-4642.2008.00512.x

78. Maxted N, Kell SP (2009) Establishment of a global network for the in situ conservation of crop wild relatives: status and needs. FAO Commission on Genetic Resources for Food and Agriculture, Rome

79. Michalski SG, Durka W, Jentsch A, Kreyling J, Pompe S, Schweiger O, Willner E, Beierkuhnlein C (2010) Evidence for genetic differentiation and divergent selection in an autotetraploid forage grass (Arrhenatherum elatius). Theor Appl Genet 120:1151-1162. https://doi.org/10.1007/s00122-009$1242-8$

80. Mitchell-Olds T, Willis JH, Goldstein DB (2007) Which evolutionary processes influence natural genetic variation for phenotypic traits? Nat Rev Genet 8(11):845-856

81. Morrell PL, Lundy KE, Clegg MT (2003) Distinct geographic patterns of genetic diversity are maintained in wild barley (Hordeum vulgare ssp. spontaneum) despite migration. Proceedings of the National Academy of Science of the USA, 100(19): 10812-10817. https://doi.org/10.1073/pnas.1633708100

82. Nevo E, Beiles A, Zohary D (1986) Genetic resources of wild barley in the Near East: structure, evolution and application in breeding. Biol J Lin Soc 27(4):355-380. https://doi.org/10.1111/j.10958312.1986.tb01742.x

83. Nevo E (1992) Origin, evolution, population genetics and resources for breeding of wild barley Hordeum spontaneum in the Fertile Crescent. In: Shewry PR (ed) Barley: genetics, biochemistry, molecular biology and biotechnology. CAB International, Wallingford, pp 19-43

84. Nevo E (2001) Evolution of genome-phenome diversity under environmental stress. Proceedings of the National Academy of Sciences of the USA, 98(11): 6233-6240. https://doi.org/10.1073/pnas.101109298

85. Nevo E, Fu YB, Pavlicek T, Khalifa S, Tavasi M, Beiles A (2012) Evolution of wild cereals during 28 years of global warming in Israel. Proceedings of the National Academy of Science of the USA, 109(9), 3412-3415. https://doi.org/10.1073/pnas.1121411109

86. Nice LM, Steffenson BJ, Blake TK, Horsley RD, Smith KP, Muehlbauer GJ (2017) Mapping agronomic traits in wild barley advanced backcross-nested association mapping population. Crop Sci 57(3):1199-1210. https://doi.org/10.2135/cropsci2016.10.0850

87. Olofsson H, Ripa J, Jonze'n N (2009) Bet-hedging as an evolutionary game: the trade-off between egg size and number. Proceedings of the Royal Society B: Biological Sciences,276(1669): 29632969. https://doi.org/10.1098/rspb.2009.0500 
88. Osborne T, Rose G, Wheeler T (2013) Variation in the global-scale impacts of climate change on crop productivity due to climate model uncertainty and adaptation. Agric For Meteorol 170:183-194

89. Pakniyat H, Powell W, Baird E, Handley LL, Robinson D, Scrimgeour CM, Hackett CA, Forster BP, Nevo E, Caligari PD (1997) AFLP variation in wild barley (Hordeum spontaneum C. Koch) with reference to salt tolerance and associated ecogeography. Genome 40(3): 332-341. https://doi.org/10.1139/g97046. PMID: 18464832

90. Parra-Quijano M, Iriondo JM, Torres E (2012) Review. Applications of ecogeography and geographic information systems in conservation and utilization of plant genetic resources. Spanish journal of agricultural research 10(2):419-429

91. Parra-Quijano M, Iriondo JM, Torres E (2012) Ecogeographical land characterization maps as a tool for assessing plant adaptation and their implications in agrobiodiversity studies. Genet Resour Crop Evol 59(2):205-217. https://doi.org/10.1007/s10722-011-9676-7

92. Paterson AH, Lin YR, Li Z, Schertz KF, Doebley JF, Pinson SR, Liu SC, Stansel JW, Irvine JE(1995) Convergent domestication of cereal crops by independent mutations at corresponding genetic loci. Science269(5231): 1714-1718. https://doi.org/10.1126/science.269.5231.1714

93. Peleg Z, Saranga Y, Krugman T, Abbo S, Nevo E, Fahima T (2008) Allelic diversity associated with aridity gradient in wild emmer wheat populations. Plant Cell Environ 31(1):39-49. https://doi.org/10.1111/j.1365-3040.2007.01731.x

94. Phillips SJ, Anderson RP, Schapire RE (2006) Maximum entropy modeling of species geographic distributions. Ecol Model 190(3-4):231-259. https://doi.org/10.1016/j.ecolmodel.2005.03.026

95. Pimentel D, Wilson C, McCullum C, Huang R, Dwen P, Flack J, Tran B, Saltman T, Cliff B (1997) Economic and environmental benefits of biodiversity. Bioscience 47:747-757

96. Qian C, Yan X, Shi Y, Yin H, Chang Y, Chen J, Ingvarsson PK, Nevo E, Ma XF (2020) Adaptive signals of flowering time pathways in wild barley from Israel over 28 generations. Heredity 124(1):62-76. https://doi.org/10.1038/s41437-019-0264-5

97. Repkova J, Dreiseitl A, Lizal P, Kyjovska Z, Teturova K, Psotkova R, Jahoor A (2006) Identification of resistance genes against powdery mildew in four accessions of Hordeum vulgare ssp. spontaneum. Euphytica 151: 23-30. https://doi.org/10.1007/s10681-006-9109-4

98. RICCAR (2017) United Nations Economic and Social Commission for Western Asia (ESCWA) et al. 2017. Arab Climate Change Assessment Report - Executive Summary. Beirut, E/ESCWA/SDPD/2017/RICCAR/Summary

99. Root TL, Price JT, Hall KR, Schneider SH, Rosenzweig C, Pounds JA (2003) Fingerprints of global warming on wild animals and plants. Nature 421:57-60. https://doi.org/10.1038/nature01333

100. Russell J, Mascher M, Dawson IK, Kyriakidis S, Calixto C, Freund F, Bayer M, Milne I, Marshall-Griffiths T, Heinen S, Hofstad A (2016) Exome sequencing of geographically diverse barley landraces and wild relatives gives insights into environmental adaptation. Nat Genet 48:1024-1030. https://doi.org/10.1038/ng.3612 
101. Saba M, Abu Hammour W, Aljaafreh S (2014) Climate change and drought atlas for Jordan. International Center for Agricultural Research in the Dry Area

102. Shakhatreh Y, Haddad N, Alrababah M, Grando S, Ceccarelli S (2010) Phenotypic diversity in wild barley (Hordeum vulgare L. ssp. spontaneum (C. Koch) Thell.) accessions collected in Jordan. Genetic Resources and Crop Evolution 57: 131-146. https://doi.org/10.1007/s10722-009-9457-8

103. Shakhatreh Y, Baum M, Haddad N, Alrababah M, Ceccarelli S (2016) Assessment of genetic diversity among Jordanian wild barley (Hordeum spontaneum) genotypes revealed by SSR markers. Genet Resour Crop Evol 63(5):813-822

104. Shaw RG, Shaw FH (2014) Quantitative genetic study of the adaptive process. Heredity 112:13-20. https://doi.org/10.1038/hdy.2013.42

105. Shi M, Michalski SG, Chen XY, Durka W (2011) Isolation by elevation: genetic structure at neutral and putatively non-neutral loci in a dominant tree of subtropical forest, Castanopsis eyrei. PLoS one 6(6):e21302. https://doi.org/10.1371/journal.pone.0021302

106. Thormann I, Fiorino E, Halewood M, Engels J (2015) Plant genetic resources collections and associated information as baseline resource for genetic diversity studies: an assessment of the IBPGR supported collections. Genet Resour Crop Evol 62(8):1279-1293. https://doi.org/10.1007/s10722-015-0231-9

107. Thormann I, Reeves P, Reilley A, Engels JM, Lohwasser U, Börner A, Richards CM (2016) Geography of genetic structure in barley wild relative Hordeum vulgare subsp. spontaneum in Jordan. PLoS one 11(8): e0160745. https://doi.org/10.1371/journal.pone.0160745

108. Thormann I, Reeves P, Thumm S, Reilley A, Engels JM, Biradar CM, Richards CM (2017) Genotypic and phenotypic changes in wild barley (Hordeum vulgare subsp. spontaneum) during a period of climate change in Jordan. Genet Resour Crop Evol 64(6):1295-1312. https://doi.org/10.1007/s10722-016-0437-5

109. UN (2015) World population prospects: the 2015 revision, Key Findings and Advance Tables, United Nations Department of Economic and Social Affairs, Population Division. Working Paper no. ESA/P/WP.241

110. Van de Wouw M, Kik C, van Hintum T, van Treuren R, Visser B (2010) Genetic erosion in crops: concept, research, results and challenges. Plant Genetic Resources: characterization utilization 8(1):1-15. https://doi.org/10.1017/S1479262109990062

111. Van Rijn CPE, Heersche I, van Berkel YEM, Nevo E, Lamers H, Poorter H (2000) Growth characteristics in Hordeum spontaneum populations from different habitats. New Phytol 146(3):471-481. https://doi.org/10.1046/j.1469-8137.2000.00670.x

112. Vincent $H$, von Bothmer R, Knüpffer $H$, Amri A, Konopka J, Maxted N (2013) Genetic gap analysis of wild Hordeum taxa. Plant Genetic Resources 10(3):242-253.

https://doi.org/10.1017/S1479262112000317

113. Volis S, Mendlinger S, Orlovsky N (2000) Variability in phenotypic traits in core and peripheral populations of wild barley Hordeum spontaneum Koch. Hereditas133(3): 235-247. 
https://doi.org/10.1111/j.1601-5223.2000.00235.x

114. Volis S, Mendlinger S, Turuspekov Y, Esnazarov U (2002) Phenotypic and allozyme variation in mediterranean and desert populations of wild barley. Hordeum spontaneum Koch Evolution 56(7):1403-1415. https://doi.org/10.1111/j.0014-3820.2002.tb01453.x

115. von Korff M, Wang H, Leon J, Pillen K (2006) AB-QTL analysis in spring barley. II. Detection of favorable exotic alleles for agronomic traits introgressed from wild barley (Hordeum vulgare ssp. spontaneum). Theor Appl Genet 112:1221-1231. https://doi.org/10.1007/s00122-006-0223-4 PMID: 16477429.

116. von Korff M, Wang H, Léon J, Pillen K (2005) AB-QTL analysis in spring barley. I. Detection of resistance genes against powdery mildew, leaf rust and scald introgressed from wild barley. Theor Appl Genet 111(3):583-590. https://doi.org/10.1007/s00122-005-2049-x PMID: 15902395.

117. International VSN, 2019. A Guide to GenStat ${ }^{\circledR}$ Release 20th. Hemel Hempstead, UK.Wang T, Ottle $C$, Peng SS, Janssens IA, Lin X, ... Ciais P (2014) The influence of local spring temperature variance on temperature sensitivity of spring phenology. Global Change Biology, 2095): 1473-1480. https://doi.org/10.1111/gcb.12509

118. Zohary D (1973) Geobotanical Foundations of the Middle East, vols 1 and 2. Gustav Fischer Verlag and Swets and Zeitlinger, Stuttgart

119. Zohary D, Hopf M, Weiss E (2012) Domestication of plants in the old world, 4th edition. Oxford: Oxford Univ Press. $264 \mathrm{p}$

\section{Figures}




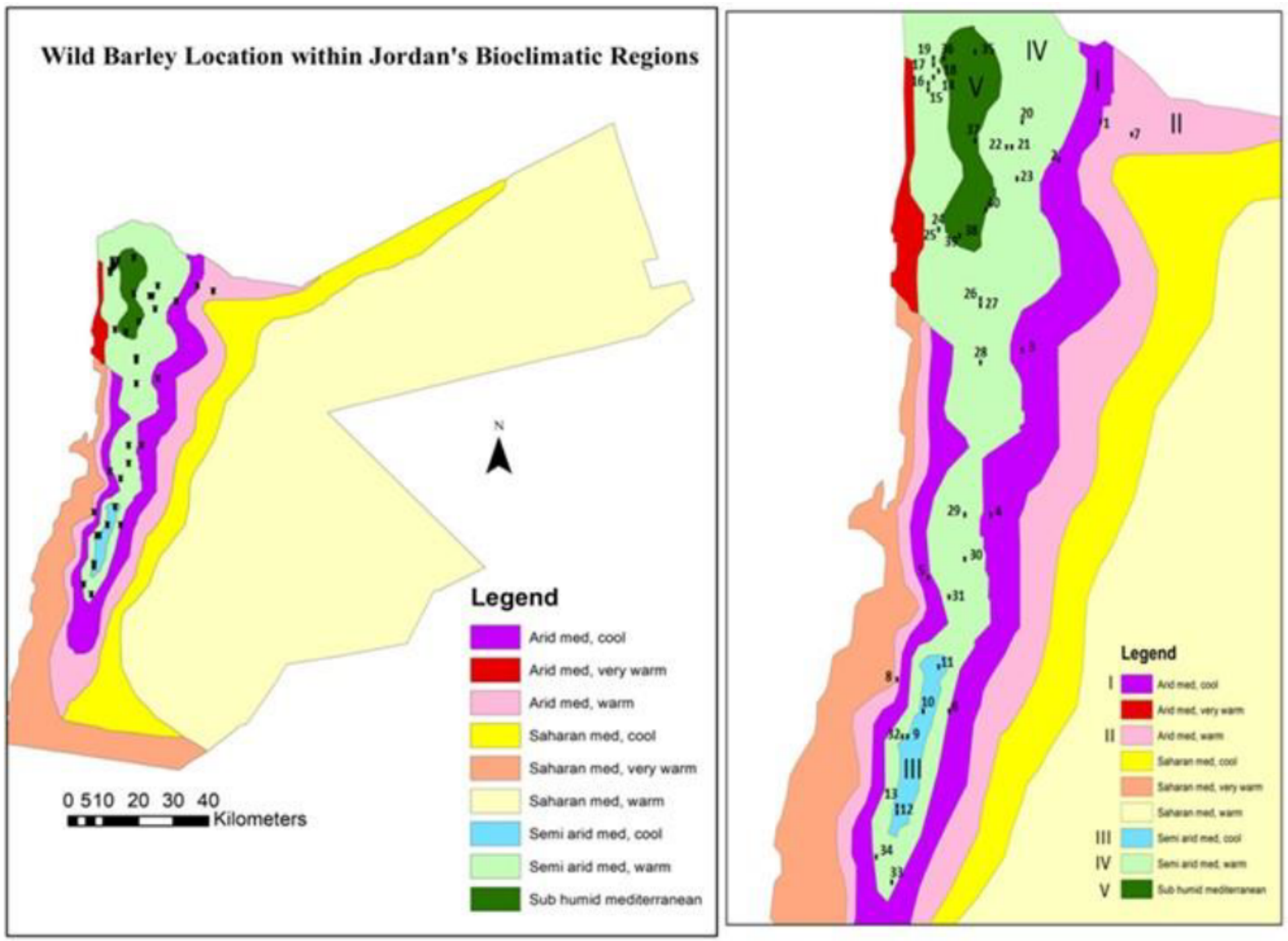

\section{Figure 1}

Geographical distribution of the collection, Hordeum vulgare subsp. spontaneum in Jordan. For bioclimatic and population codes, refer to Table 1. 


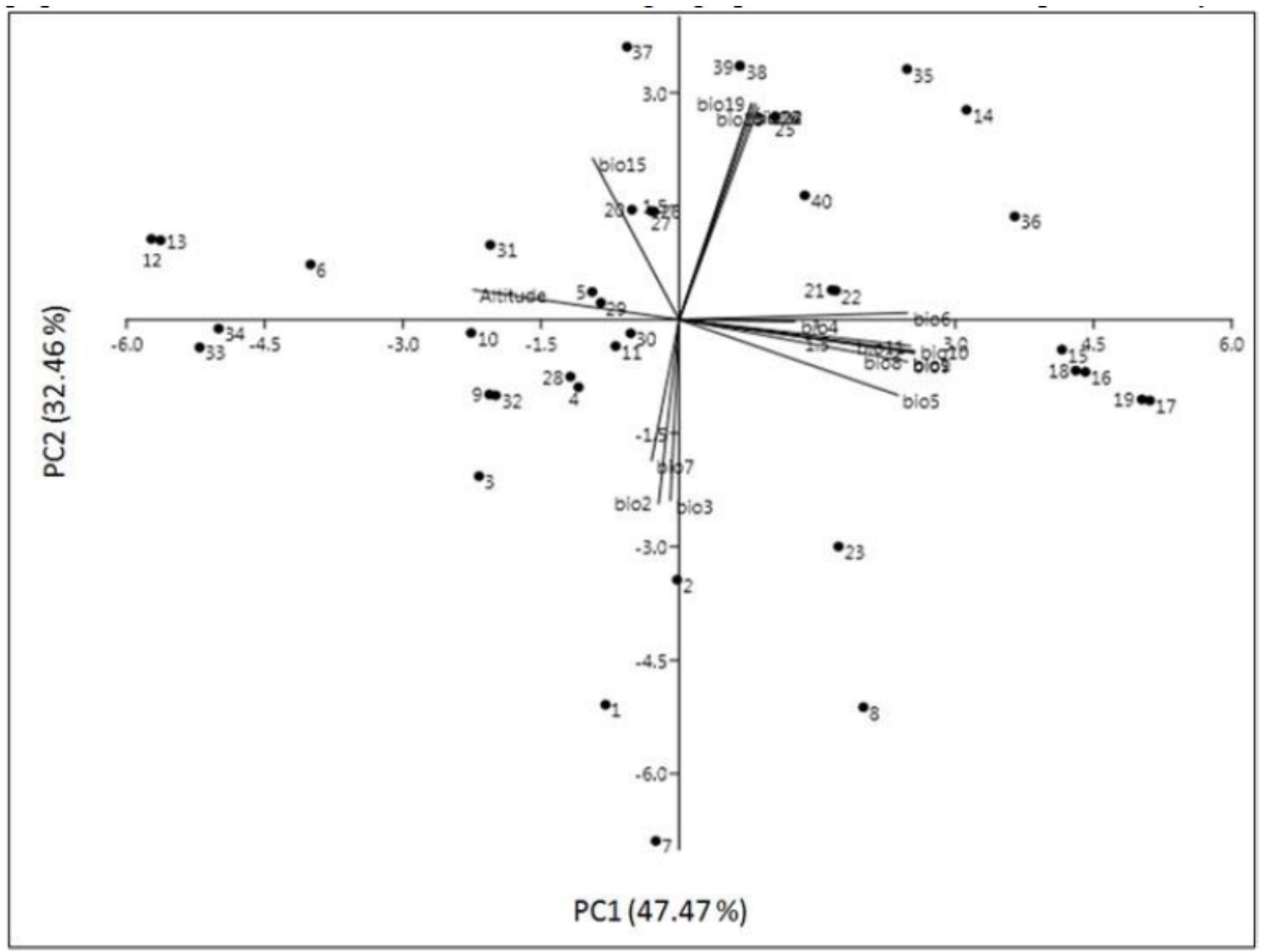

Figure 2

Principal component analysis (PCA) for 40 wild barley populations from different collection sites and 17 climate variables and altitude. Filled dots represent the wild barley population collection sites, while climate and geographical variables are represented by vectors. 


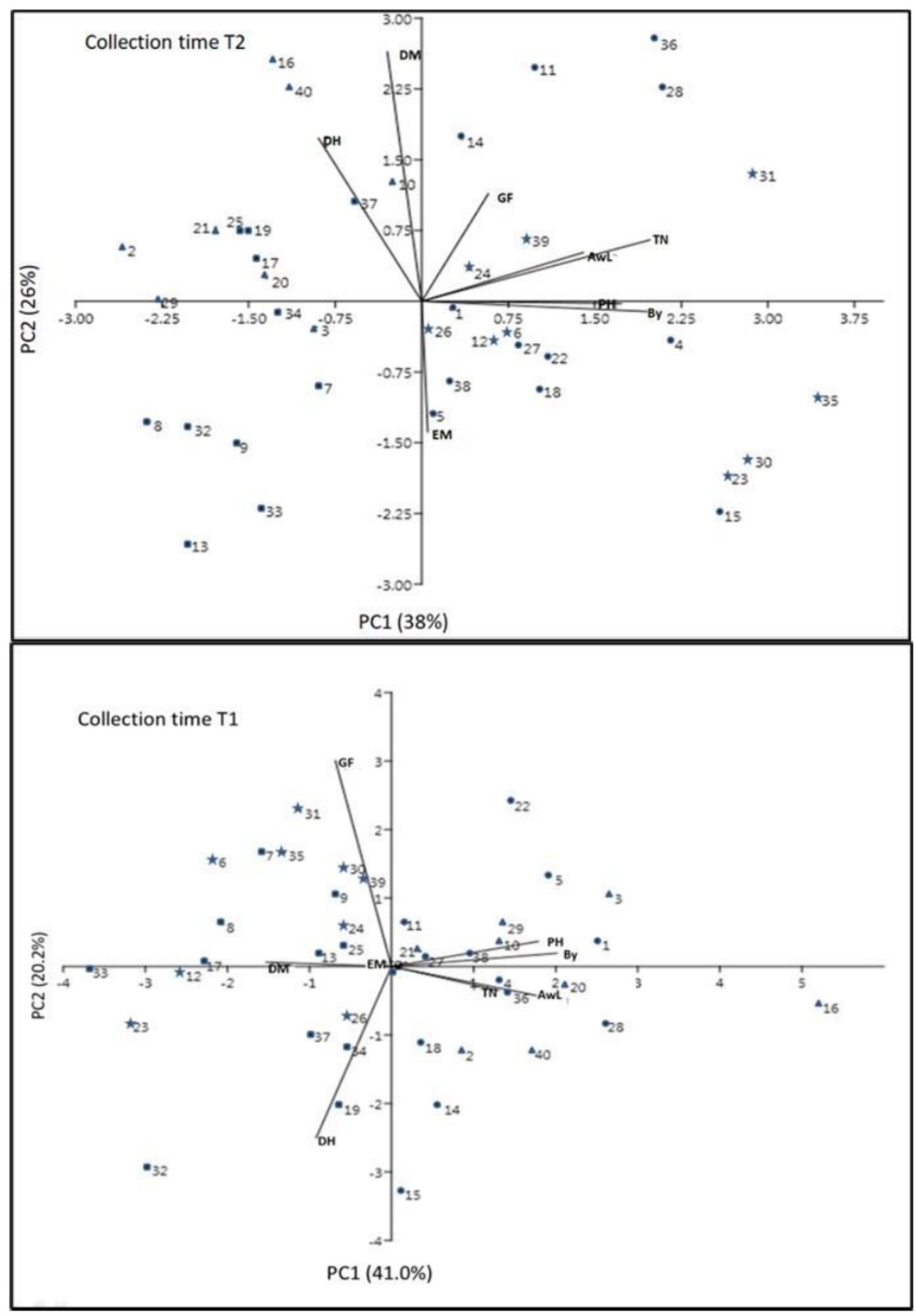

Figure 3

Principal component analysis (PCA) for Hordeum vulgare ssp. spontaneum collected at 40 sites in 1991 (T1) and 2014 (T2). Filled dots represent sites with similar performance in PC1 from both collection times; squares represent sites with similar performance in PC2 from both collection times; triangles represent sites from collection times T1 in PC1 with different performance in PC2 when collected at T2; stars represent sites from collection times T1 in PC2 with different performance in PC1 when collected at 
$\mathrm{T1}$. $(\mathrm{Em}=$ plant emergence, $\mathrm{Dh}=$ day of flowering, $\mathrm{Dm}=$ day of maturity, $\mathrm{Gf}=$ grain filling duration, $\mathrm{Ph}=$ plant height, $\mathrm{Tn}=$ tiller number, $\mathrm{Awl}=$ awn length and $\mathrm{By}=$ biological yield .

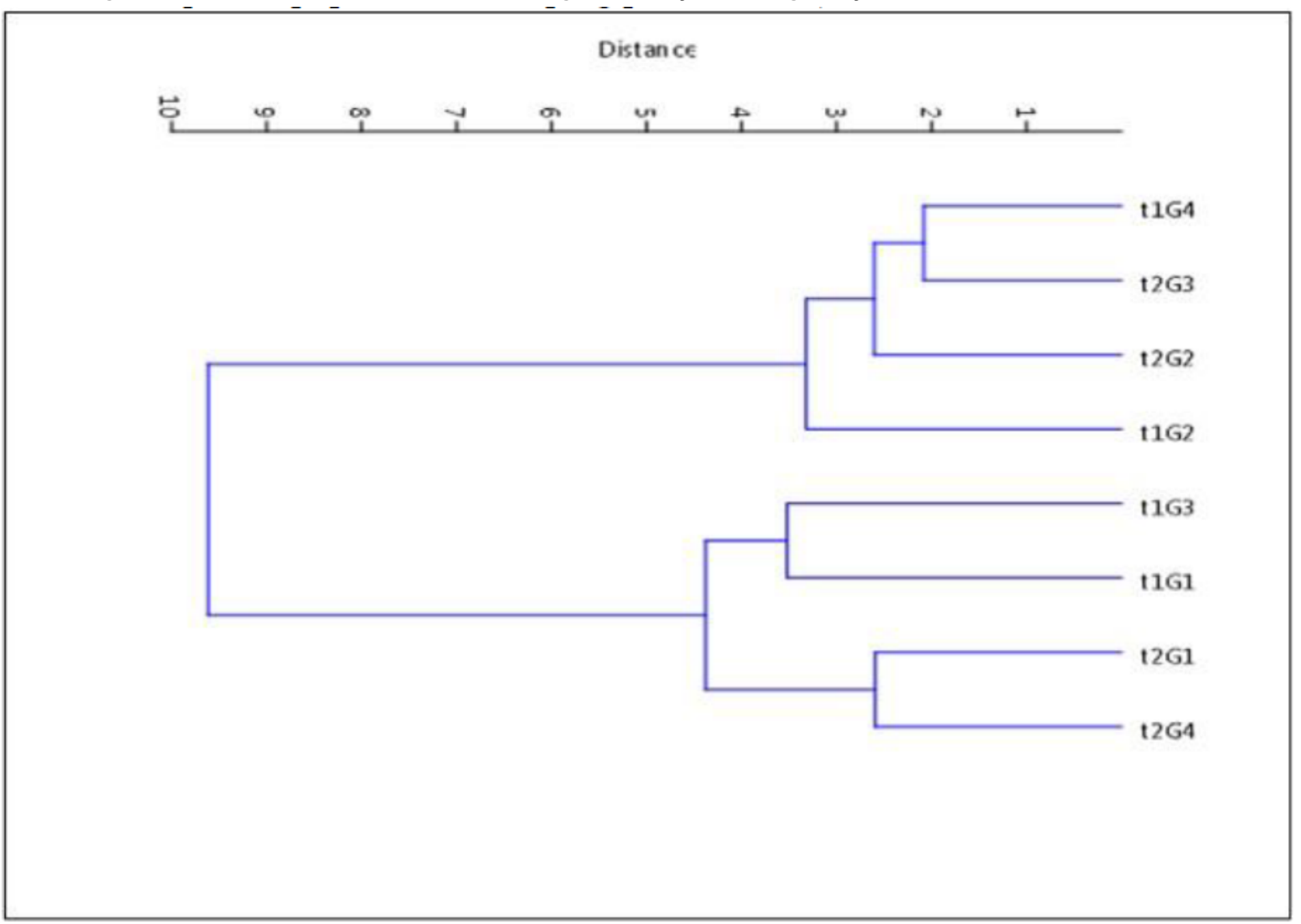

Figure 4

Dendrogram based on phenotypic distance: Method = UPGMA using morphological traits the population groups based on the time of collection and performance ( $t$ equal to the time of collection and $\mathrm{G}$ equal of population Grouping performance). 


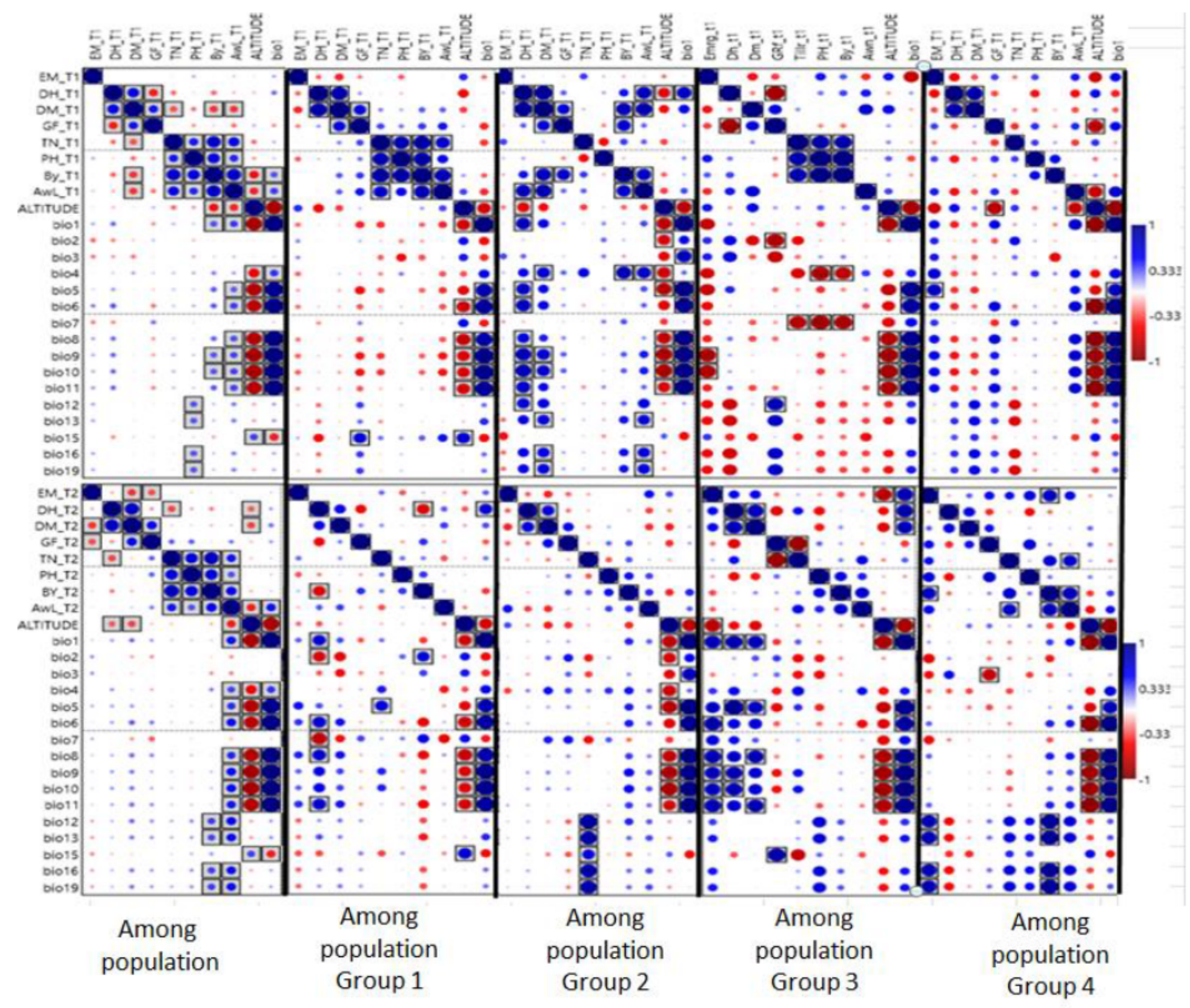

Figure 5

Correlation coefficients between the phenotypic traits collected on 40 Hordeum vulgare ssp. spontaneum populations and both bioclimate variables and altitude, based on collection times T1 (1994) and T2 (2014). Blue circle $=$ positive correlation, red circle $=$ negative correlation and box significant $\leq 0.05$. 


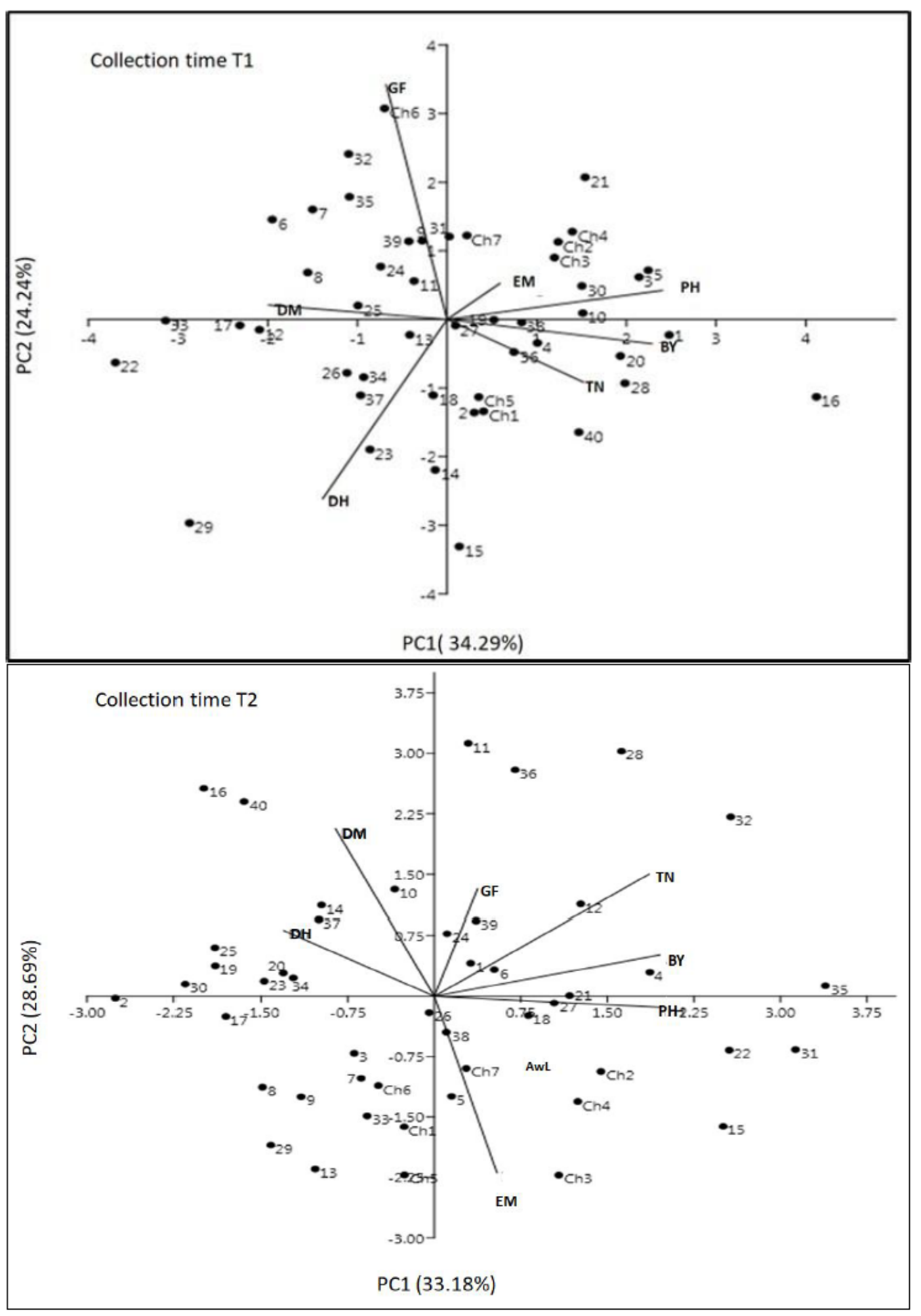

\section{Figure 6}

Principal component analysis (PCA) of the phenotypic traits recorded on 40 populations of Hordeum vulgare ssp. spontaneum from two collection times ( $T 1=1991$ and $T 2-2014)$ and 7 improved cultivars; Ch1 =ACSAD 176, Ch2 = Yarmouk, Ch3 = Muta'a, Ch4 = Kv, Ch5 = Baladi, Ch6. = Athrouh and Ch7 = Rum. 